\title{
Ultrastructural and physiological responses of potato (Solanum tuberosum L.) plantlets to gradient saline stress
}

\section{Hui-Juan Gao ${ }^{1+}$, Hong-Yu Yang ${ }^{1+}$, Jiang-Ping Bai ${ }^{1}$, Xin-Yue Liang ${ }^{2}$, Yan Lou ${ }^{1}$, Jun-Lian Zhang ${ }^{1}$, Di Wang ${ }^{1}{ }^{*}$, Jin-Lin Zhang ${ }^{3}$, Shu-Qi Niu ${ }^{3}$ and Ying-Long Chen ${ }^{4,5}$}

\author{
Gansu Key Laboratories of Crop Genetic and Germplasm Enhancement and Aridland Crop Science, College of Agronomy, Gansu Agricultural University, Lanzhou, \\ China \\ 2 Department of Chemistry, School of Chemistry and Chemical Engineering, Nanjing University, Nanjing, China \\ ${ }^{3}$ State Key Laboratory of Grassland Agro-ecosystems, College of Pastoral Agriculture Science and Technology, Lanzhou University, Lanzhou, China \\ ${ }^{4}$ Plant Nutrition and Soil Science and UWA Institute of Agriculture, School of Earth and Environment, The University of Western Australia, Perth, WA, Australia \\ ${ }^{5}$ State Key Laboratory of Soil Erosion and Dryland Farming on the Loess Plateau, Institute of Soil and Water Conservation, Chinese Academy of Sciences and \\ Ministry of Education, Northwest A\&F University, Yangling, China
}

\section{Edited by:}

Mary Jane Beilby, The University of New South Wales, Australia

\section{Reviewed by:}

Huazhong Shi, Texas Tech

University, USA

Vadim Volkov, London Metropolitan

University, UK

\section{*Correspondence:}

Di Wang, Gansu Key Laboratories of Crop Genetic and Germplasm Enhancement and Aridland Crop Science, College of Agronomy, Gansu Agricultural University, 1 Yingmen Village, Anning District, Lanzhou 730070, Gansu, China e-mail:wangd@gsau.edu.cn; Jin-Lin Zhang, State Key Laboratory of Grassland Agro-ecosystems, College of Pastoral Agriculture Science and Technology, Lanzhou University, 768 West Jiayuguan Road, Chengguan District, Lanzhou 730020, Gansu, China

e-mail: jlzhang@|zu.edu.cn

tThese authors have contributed equally to this work.
Salinity is one of the major abiotic stresses that impacts plant growth and reduces the productivity of field crops. Compared to field plants, test tube plantlets offer a direct and fast approach to investigate the mechanism of salt tolerance. Here we examined the ultrastructural and physiological responses of potato (Solanum tuberosum L. c.v. "Longshu No. 3") plantlets to gradient saline stress (0, 25, 50, 100, and $200 \mathrm{mM} \mathrm{NaCl}$ ) with two consequent observations ( 2 and 6 weeks, respectively). The results showed that, with the increase of external $\mathrm{NaCl}$ concentration and the duration of treatments, (1) the number of chloroplasts and cell intercellular spaces markedly decreased, (2) cell walls were thickened and even ruptured, (3) mesophyll cells and chloroplasts were gradually damaged to a complete disorganization containing more starch, (4) leaf $\mathrm{Na}$ and $\mathrm{Cl}$ contents increased while leaf $\mathrm{K}$ content decreased, (5) leaf proline content and the activities of catalase (CAT) and superoxide dismutase (SOD) increased significantly, and (6) leaf malondialdehyde (MDA) content increased significantly and stomatal area and chlorophyll content decline were also detected. Severe salt stress (200 mM NaCl) inhibited plantlet growth. These results indicated that potato plantlets adapt to salt stress to some extent through accumulating osmoprotectants, such as proline, increasing the activities of antioxidant enzymes, such as CAT and SOD. The outcomes of this study provide ultrastructural and physiological insights into characterizing potential damages induced by salt stress for selecting salt-tolerant potato cultivars.

Keywords: potato plantlets, saline stress, ultrastructure, antioxidant defense system, ion distribution

\section{INTRODUCTION}

As a major abiotic stresses, salinity affects plant growth and significantly reduces crop yield (Zhang et al., 2010; Zhang and Shi, 2013; Deinlein et al., 2014; Shabala et al., 2014). High soil salinity can lead to osmotic imbalance, ion-specific toxicity, alteration of composition and structure of membranes, and disruption of photosynthesis (Hasegawa et al., 2000; Zhang and Shi, 2013; Maathuis et al., 2014; Cabot et al., 2014; Zhang et al., 2014). Plants generally develop salt resistance mechanism and unique structures to survive under high saline-stress conditions (Deinlein et al., 2014; Gupta and Huang, 2014; Roy et al., 2014; Shabala et al., 2014). Therefore, a better understanding of the structural variations, ion distribution and physiological changes in crop plants induced by salinity should facilitate the identification of saline tolerance mechanisms (Roy et al., 2014).

Potato (Solanum tuberosum L.), as the fourth most important food crop in the world, has been identified as moderately saltsensitive or salt-tolerant (Katerji et al., 2000). Under $50 \mathrm{mM} \mathrm{NaCl}$ treatment, potato growth decreased and tuber yield reduced to about $50 \%$, while the growth of plants is completely inhibited at $150 \mathrm{mM} \mathrm{NaCl}$ (Hmida-Sayari et al., 2005). Bruns and HechtBuchholz (1990) found that the salt-induced changes were mainly observed in the chloroplasts, especially in the thylakoids. Different potato cultivars reacted differently to salt stress. Mitsuya et al. (2000) found the degradation of thylakoid membranes of chloroplast of sweet potato in vitro resulting from salt-induced oxidative stress $(0$ and $80 \mathrm{mM})$. In addition, ultrastructural changes at the cellular level in a salt-adapted potato callus lines grown in $150 \mathrm{mM} \mathrm{NaCl}$ (Queirós et al., 2011) demonstrated that saltadapted potato cell line contained more large starch, reduced membrane system and no vesicles. Although the ultrastructural alterations induced by saline have been reported in many plant cells (Yamane et al., 2004; Miyake et al., 2006; Ferreira and Lima-Costa, 2008; Bennici and Tani, 2009, 2012), information regarding the effects of salinity on potato cells cultured in vitro is not specified and is incomplete. 
Plants could sense changes of external environment and adapt to new conditions (Vij and Tyagi, 2007; Cabot et al., 2014; Deinlein et al., 2014). Plants have developed complex physiological and biochemical mechanisms to maintain a stable intracellular environment through accumulating various antioxidant enzymes and solute under salt stress (Wang et al., 2007; Zhang and Shi, 2013; Gupta and Huang, 2014; Roy et al., 2014). The osmotic adjustment in plant can maintain water uptake and cell turgor, allowing regular physiological metabolism (Serraj and Sinclair, 2002; Han et al., 2014). Proline, as an important osmosis protective agent, contributes to osmotic adjustment, protecting cells from damage (Silva-Ortega et al., 2008; Abrahám et al., 2010; Hou et al., 2013; Bojorquez-quintal et al., 2014; Gupta and Huang, 2014). Salt stress also caused overproduction of reactive oxygen species (ROS), leading to secondary oxidative stress (Nounjan et al., 2012; Mishra et al., 2011). ROS mainly generated from chloroplasts and mitochondria (Munns and Tester, 2008), attributed to membrane damage (Abdullahil-Baque et al., 2010), decrease of protein synthesis and inactivation of enzymes, seriously disrupting cell normal metabolism and inducing lipid peroxidation (Csiszár et al., 2012). Malondialdehyde (MDA) as a product of membrane lipid peroxidation could reflects oxidative damage to cell membrane (Koca et al., 2006; Yazici et al., 2007; Han et al., 2014). To avoid ROS-induced oxidative damage, plants could form antioxidant defense system to remove free radical and effectively avoid oxidative damage. Therefore, the increase of catalase (CAT) and superoxide dismutase (SOD) activity is correlated to the tolerance of plant to abiotic stresses (Hernández et al., 1993; Hossain et al., 2004; Daneshmand et al., 2010). Salt-tolerant potato could evolve a better protective mechanisms to detoxifying ROS by increasing the activity of antioxidant enzymes and content of proline (Arbona et al., 2008; Cho et al., 2012).

Higher accumulation of salt ions in leaves is very harmful for plant growth (Neocleous and Vasilakakis, 2007; Sabra et al., 2012; Khayyat et al., 2014; Liu et al., 2014a). Naeini et al. (2006) reported that more $\mathrm{Na}^{+}$accumulated in roots and more $\mathrm{Cl}^{-}$in leaves of pomegranates (Punica granatum) exposed to salt stress. Soil salinity usually reduces $\mathrm{K}^{+}$uptake by roots of higher plants (Zhang et al., 2010; Maathuis et al., 2014). Recent research suggests that maintaining a high level of $\mathrm{K}^{+} / \mathrm{Na}^{+}$ratio is important to salt tolerance in glycophytes (Maathuis and Amtmann, 1999; Carden et al., 2003; Peng et al., 2004; Lv et al., 2011; Maathuis et al., 2014). A number of studies have demonstrated that salinity also reduced $\mathrm{Ca}^{2+}$ absorption and transportation in plant (Tattini and Traversi, 2009; Evelin et al., 2012; Zhang and Shi, 2013; Liu et al., 2014a). $\mathrm{Ca}^{2+}$ has vital signal transduction function triggered by various environmental stresses. Especially, $\mathrm{Ca}^{2+}$ could alleviate $\mathrm{Na}^{+}$toxicity on plants and has a regulation effect on ion selectivity absorption and transport (Zhu, 2002; BenAmor et al., 2010). $\mathrm{Ca}^{2+}$ is an essential component of the middle lamella and cell walls which participates in maintaining the stability of cell membrane, cell wall, and membrane-bound proteins, preventing membrane damage and leakage, and stabilizing wall structure (Maathuis and Amtmann, 1999; Liu et al., 2014a). Scanning electron microscope (SEM) equipped with energy dispersive X-ray Spectroscopy (EDX) has been extensively utilized for analysis of the elements distributed in plant tissues. Moreover, ion concentrations analyzed by EDX is comparable to that derived from atomic absorption or flame photometry of whole samples (Ebrahimi and Bhatla, 2011, 2012).

The present study was to investigate the anatomical response, ion distribution and physiological changes of potato plants to gradient salt $(\mathrm{NaCl})$. Test tube plantlets were used in this study to allow a direct and fast approach to examine the physiological and biochemical mechanisms of salt tolerance. The present study will provide the insight of the anatomical response, in addition to physiological response, of in vitro propagated potato plantlets exposed to saline stress, and develop a useful method for screening salt-tolerant cultivars.

\section{MATERIALS AND METHODS PLANT MATERIAL AND TREATMENTS}

A local potato cultivar "Longshu No. 3," released in 2002 by Gansu Academy of Agricultural Sciences, China, was used in this study. This cultivar has been largely grown in Northwestern China because of its moderate resistance to low temperature, drought and salinity. Potato plantlets were propagated in solidified Murashige and Skoog (MS) medium. A total of 6 plantlets were cultured in each triangular flask under $16 / 8 \mathrm{~h}$ photoperiods at $200 \mu \mathrm{mol} / \mathrm{m}^{2} / \mathrm{s}$ and $23 \pm 2^{\circ} \mathrm{C}$. For salt stress treatment, plantlet stems with at least two leaves were transferred to the MS medium containing $\mathrm{NaCl}$ at concentrations of 0 (control), 25, 50, 100, and $200 \mathrm{mM}$, respectively. Root, stem and leaf samples were collected 2 or 6 weeks after treatments for analysis. There were six plantlets in six triangular flasks for each treatment.

\section{TRANSMISSION ELECTRON MICROSCOPY}

At each sampling time, the fully expanded uppermost leaves of potato plantlets were collected and fixed for $3 \mathrm{~h}$ at room temperature with $2 \%$ glutaraldehyde in $100 \mathrm{mM}$ sodium cacodylate buffer with a pH value of 7.4 (Sabatini et al., 1963). Samples were post-treated in $1 \%(\mathrm{w} / \mathrm{v}) \mathrm{OsO}_{4}$, similarly buffered for $6 \mathrm{~h}$ at room temperature, dehydrated in a graded ethanol series and propylene oxide, and infiltrated and embedded in Spurr's epoxy resin (Spurr, 1969). Ultrasections were obtained using a LKBV ultramicrotome and stained with uranyl acetate and lead phosphate. Images were observed and generated using a transmission electron microscope (JEM-1230 JEOL, Japan). The size of the intercellular space and cell wall was measured manually on the printed micrographs.

\section{X-RAY MICROANALYSIS OF IONS}

Root, shoot and leaf samples of each treatment were washed with distilled water, respectively. The middle sections of plant tissues were dipped in $5 \%$ agar, inserted to a depth of $1.0 \mathrm{~cm}$ in a copper holder, and sliced freehand with a razor blade to obtain transverse sections, and immediately frozen in liquid nitrogen. The samples were freeze-dried in vacuum and stored in a desiccator, followed by carbon coated with a high vacuum sputter coater and sputter-coated with gold in an argon atmosphere. Samples were analyzed in an scanning electron microscope (JSM$5600 \mathrm{LV}$, JEOL, Japan) equipped with energy dispersive X-ray spectroscopy (INCA X-Max 80, Oxford Instruments) detector. The accelerating voltage was $10 \mathrm{kV}$. The counting time for each 
analysis was $60 \mathrm{~s}$ and the data were expressed as counts per second (cps) of an element peak after subtraction of the background. Then, these spectra were transformed to normalized data. All the detectable elements were transformed into the relative element weight. Counts per second of $\mathrm{K}, \mathrm{Na}$, and $\mathrm{Cl}$ were discerned by weight percentage in tissues. Five location spots of the same tissue of each section were analyzed.

\section{PHYSIOLOGICAL ASSAYS}

Free proline and malondialdehyde content from plantlet were extracted and quantified following the ninhydrin-based colorimetric assays (Delauney et al., 1992) and thiobarbituric acid (Hodges et al., 2014), respectively. Activities of SOD and CAT were determined according to the ultraviolet absorption method assays of Giannopotitis and Ries (1977) and Stewart and Bewley (1980). To measure the stomatal aperture, leaf samples $(2 \times$ $2 \mathrm{~mm}$ ) were collected from plantlets treated with or without $\mathrm{NaCl}$ stress. The lower epidermis of leaves was collected by scotch tape and examined under a compound Digital Microscope (Motic) after stained with $0.1 \%$ I-KI. The morphological parameters of stomata [guard cell length-L $(\mu \mathrm{M})$ and guard cell width-W $(\mu \mathrm{M})]$ magnified $200 \times$, were measured with Motic Images Advanced 3.2. Stomatal area $(S)$ was calculated as the product of L and W. Leaf chlorophyll content was determined spectrophotometrically in $80 \%$ acetone as described by Arnon (1949).

\section{DATA ANALYSIS}

Parameter data were presented as means with standard deviations $(n=6)$. Data were subjected to One-Way ANOVA and Duncan's multiple range tests for each parameter at $P<0.05$ using SPSS 13.0.

\section{RESULTS}

\section{EFFECTS OF SALINE STRESS ON THE ULTRASTRUCTURE OF LEAF MESOPHYLL CELLS}

For 2 weeks of control plantlets (without salt stress), the ultrastructural distortion of mesophyll cells and chloroplasts was not observed. The structure of mesophyll cell was intact and the cell membrane was in close contact with the cell wall. Moreover, there was large intercellular space in mesophyll cells (Figure 1A). After 6 weeks growth, integrated chloroplasts of control plantlets were still closely arranged along plasma membrane (Figure 1B, Table 1).

For plantlets with 2 weeks of $25 \mathrm{mM} \mathrm{NaCl}$ treatment, mesophyll cell walls were twisted and plasma membrane crimpled remarkably. A small proportion of the chloroplasts with distended thylakoids were apart from the cell wall and membranous invagination was observed (Figure 1C). After 6-week treatment more starch grains were attached to the chloroplasts (Figure 1D) and intercellular space decreased (Table 1). For plantlets grown in $50 \mathrm{mM} \mathrm{NaCl}$ for 2 weeks, mesophyll cells showed some alterations (Figure 1E). The number of chloroplast decreased dramatically. Plasmolysis in some cells was accompanied by a reduction in mesophyll intercellular spaces. Six weeks later, chloroplasts showed irregular shape and complex vesiculation in the vacuoles was observed. Moreover, a number of cells appeared to be linked together without space (Figure 1F, Table 1). When plantlets

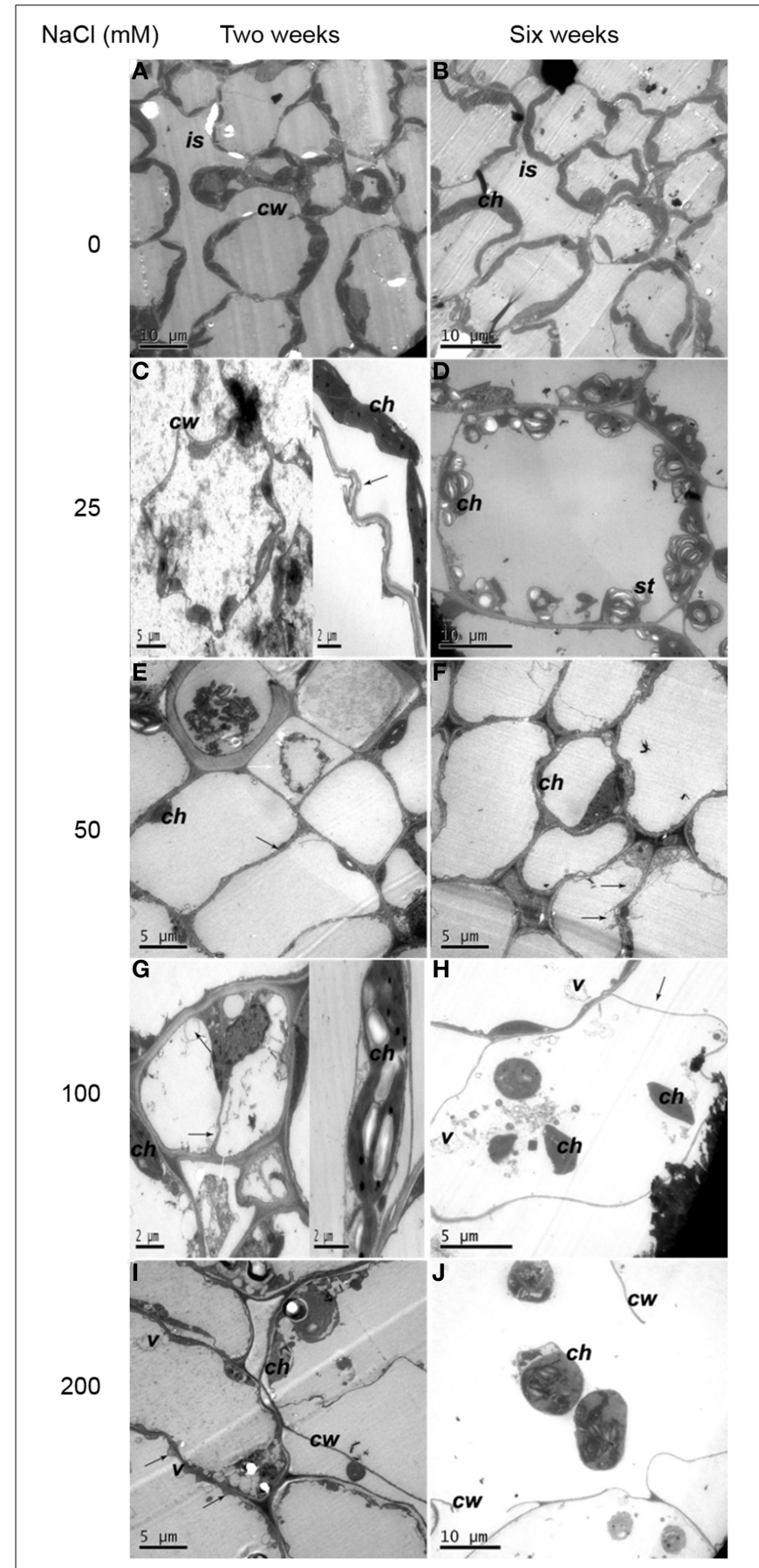

FIGURE 1 | Ultrastructural changes of mesophyll cells. (A) Two weeks of non-salinity: intact mesophyll cells 2 weeks of non-salinity treatment. (B) Six weeks of non-salinity: more chloroplasts were present in mesophyll cells and cellular intercellular spaces increased for 6 weeks of $25 \mathrm{mM} \mathrm{NaCl}$ treatment. (C) Two weeks of $25 \mathrm{mM} \mathrm{NaCl}$ : cell walls were twisted, and the plasma membrane was apparently crimpled. Note chloroplasts were apart from the cell walls with membranous invaginations (black arrows). (D) Six weeks of $25 \mathrm{mM} \mathrm{NaCl}$ : mesophyll cell-contained chloroplasts have more starch grains. (E) Two weeks of $50 \mathrm{mM} \mathrm{NaCl}$ : mesophyll cells displayed plasmolysis (white arrow) and reduced intercellular spaces (black arrow). (F) Six weeks of $50 \mathrm{mM} \mathrm{NaCl}$ : complex vesiculation (black arrows), and dramatically reduced numbers of chloroplasts. (G) Two weeks of $100 \mathrm{mM}$

(Continued) 


\section{FIGURE 1 | Continued}

$\mathrm{NaCl}$ : plasmolysis (white arrow), numerous vesicles (black arrows) and embedded chloroplasts. (H) Six weeks of $100 \mathrm{mM} \mathrm{NaCl}$ : cells showed severe plasmolysis (black arrows) and more vesicles and chloroplasts moved toward the cell center. (I) Two weeks of $200 \mathrm{mM} \mathrm{NaCl}$ : cells displayed severely damaged membrane systems, with severe membranous invagination (black arrow). (J) Six weeks of $200 \mathrm{mM} \mathrm{NaCl}$ : cell walls ruptured, and whole cells disintegrated. Note: ch, chloroplast; g, grana; pl, plastoglobuli; st, starch grains; w, cell wall; is, intercellular space; v, vesicle.

Table 1 | Size of the Intercellular space and cell wall of the Mesophyll cell.

\begin{tabular}{lccccc}
\hline $\mathbf{N a C l}(\mathbf{m M})$ & $\mathbf{0}$ & $\mathbf{2 5}$ & $\mathbf{5 0}$ & $\mathbf{1 0 0}$ & $\mathbf{2 0 0}$ \\
\hline $\begin{array}{l}\text { Intercellular } \\
\text { space }(\mu \mathrm{m})\end{array}$ & $6.41 \pm 0.57 \mathrm{a}$ & $2.34 \pm 0.07 \mathrm{~b}$ & $0 \pm 0 \mathrm{c}$ & $0 \pm 0 \mathrm{c}$ & NA \\
$\begin{array}{l}\text { Cell wall } \\
(\mu \mathrm{m})\end{array}$ & $0.18 \pm 0.02 \mathrm{a}$ & $0.19 \pm 0.01 \mathrm{a}$ & $0.18 \pm 0.00 \mathrm{a}$ & $0.26 \pm 0.02 \mathrm{~b}$ & $\mathrm{NA}$ \\
& & & & &
\end{tabular}

Values are means \pm standard deviation $(n=6)$. Means in each line followed by different letters were statistically different $(P<0.05)$ by Duncan's multiple range tests. NA, not available. At $200 \mathrm{mM}$, parameters could not be obtained due to cell wall rupture and cell disintegration.

were exposed to $100 \mathrm{mM} \mathrm{NaCl}$ for 2 weeks, serious plasmolysis was observed. Membranous invaginations resulted in numerous vesicles. Some chloroplasts embedded together (Figure 1G). Six weeks later, plasmolysis occurred severely accompanied by the presence of more vesicles in the vacuole. Chloroplasts moved toward the center of the cell (Figure 1H). The most dramatic alterations were observed in plantlets treated with $200 \mathrm{mM} \mathrm{NaCl}$ for 2 weeks. Membrane structure was severely damaged, characterized by severe membranous invagination (Figure 1I). After 6 weeks of $200 \mathrm{mM} \mathrm{NaCl}$ treatment, cell walls ruptured and the whole cell disorganized (Figure 1J).

\section{EFFECTS OF SALINE STRESS ON THE ULTRASTRUCTURE OF CHLOROPLASTS}

For 2 weeks of control plantlets, integrated chloroplasts with few and small starch, containing compactly arranged thylakoids and well compartmentalized grana stacks with distinct grana lamellaes parallel to the chloroplasts' long axes, were observed (Figure 2A). Six weeks later, the membrane system was complete. The grana and stromal lamellae of chloroplast closely arranged and compacted thylakoids (Figure 2B).

When exposed to $25 \mathrm{mM} \mathrm{NaCl}$ for 2 weeks, the cell walls were thickened (Figure 2C, Table 1). The outer membrane of the chloroplast was vague. After 6 weeks of $25 \mathrm{mM} \mathrm{NaCl}$ treatment, the swelling of the thylakoids became obvious. The arrangement of lamella remained consistent, but showed a slight bend (Figure 2D). After 2 weeks of $50 \mathrm{mM} \mathrm{NaCl}$ treatment, chloroplast envelope was partially fragmented and evaginated to form complex vesicles (Figure 2E). Six weeks later, chloroplast envelopes disrupted with outer membranes disorganized. Grana lamella loosened with severely swollen thylakoids and space between lamella increased (Figure 2F). For plantlets treated with $100 \mathrm{mM}$ $\mathrm{NaCl}$ for 2 weeks, the cell walls were much thicker (Table 1).

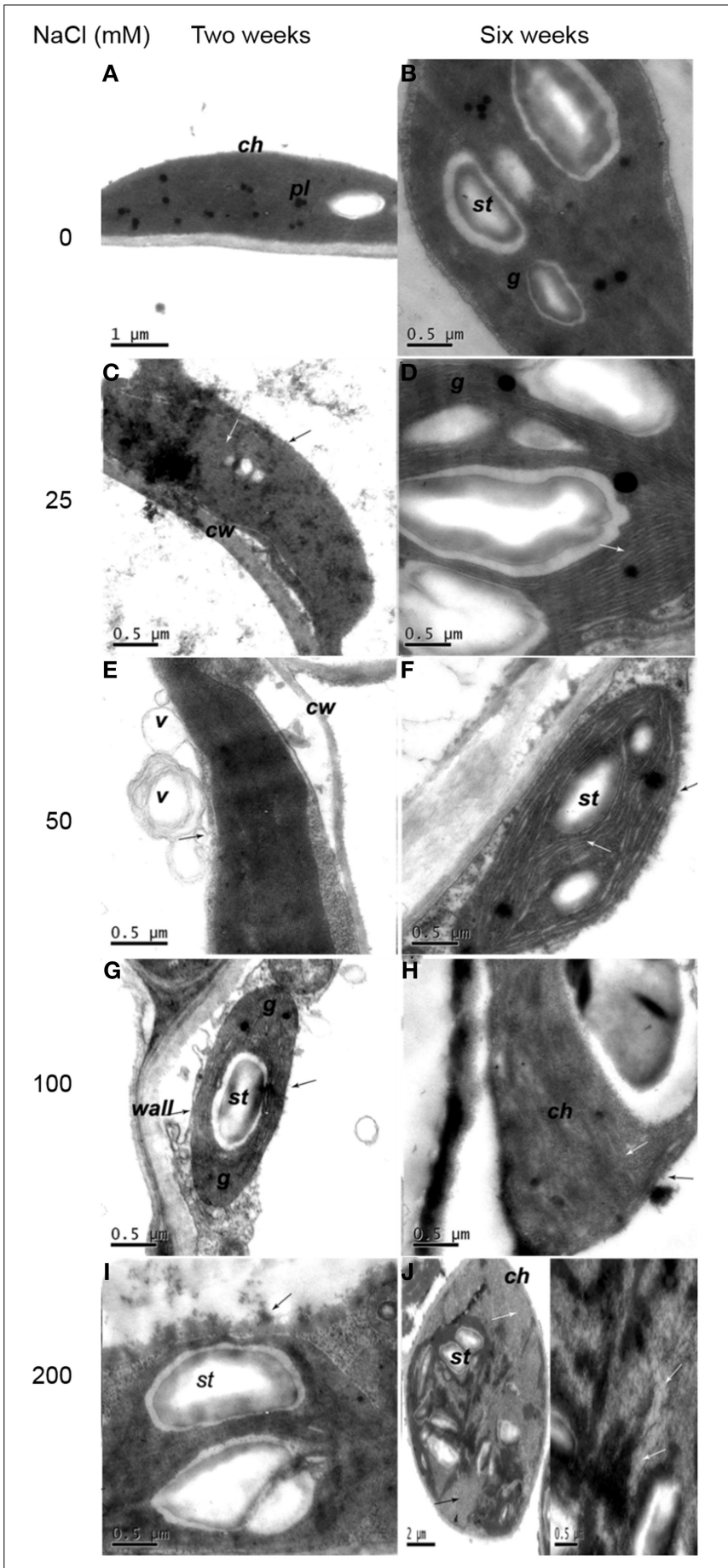

FIGURE 2 | Ultrastructural changes of chloroplast in mesophyll cell. (A) Two weeks of non-salinity: ellipse- or spindle-shaped chloroplast with few and small starch. (B) Six weeks of non-salinity: chloroplast structure was complete. (C) Two weeks of $25 \mathrm{mM} \mathrm{NaCl}$ : chloroplast with vague outer membranes (black arrows) showed distended thylakoids (white arrows). (D) Six weeks of $25 \mathrm{mM} \mathrm{NaCl}$ : obvious swelling of the thylakoid (white arrow). (E) Two weeks of $50 \mathrm{mM} \mathrm{NaCl}$ : chloroplast envelope evagination, forming vesicles (black arrow). (F) Two weeks of $50 \mathrm{mM} \mathrm{NaCl}$ : chloroplast envelope disruption (black arrow) and distorted lamella (white arrow). (G) Two weeks of $100 \mathrm{mM} \mathrm{NaCl}$ : chloroplast envelope disintegration (black arrow) and thicker cell walls and partially dissolved grana thylakoid. (H) Six

(Continued) 


\section{FIGURE 2 | Continued}

weeks of $100 \mathrm{mM} \mathrm{NaCl}$ : envelope (black arrow) and lamellar structure (white arrow) partly dissolved. (I) Two weeks of $200 \mathrm{mM} \mathrm{NaCl}$ : chloroplast disintegrated with inclusions effused (black arrows). (J) Six weeks of $200 \mathrm{mM} \mathrm{NaCl}$ : the grana and stromal lamella of chloroplast digest basically (black arrow), while thylakoids disintegrate and cavitate gradually (white arrows). Note: ch, chloroplast; g, grana; pl, plastoglobuli; st, starch grains; w, cell wall; is, intercellular space; v, vesicle.

Chloroplast envelope disintegrated and the grana thylakoid dissolved partially with reduced grana stacking, characterized by the presence of enlarged plastoglobuli and starch grains (Figure 2G). Six week later, the orientation of grana changed. Lamellar stacking decreased and dissolved dramatically. Membrane system was indistinct (Figure 2H). The most serious impact was observed when plantlets were treated with $200 \mathrm{mM} \mathrm{NaCl}$. Some chloroplasts disintegrated with inclusions effused for plantlets treated with $200 \mathrm{mM} \mathrm{NaCl}$ for 2 weeks (Figure 2I). Six weeks later, the grana and stromal lamella of round chloroplasts with some starch grains digested basically, thylakoid membranes adhered to each other, while thylakoids disintegrated, cavitated, and even gradually disappeared (Figure 2J).

\section{EFFECTS OF SALINE STRESS ON ION DISTRIBUTION IN POTATO PLANTLET TISSUES}

$\mathrm{Na}$ and $\mathrm{Cl}$ contents in leaves were relatively higher than that in stems and roots for all treatments. After 2 week treatments, $\mathrm{Na}$ relative content in leaves was 5.1, 4.2, 3.4, 3.0, and 1.9 times of that in roots at $0,25,50,100,200 \mathrm{mM} \mathrm{NaCl}$ treatments, respectively; $\mathrm{Cl}$ relative content in leaves was $1.2,4.4,2.5,6.4$, and 5.0 times of that in roots, respectively. After 6 week treatments, with the increase of $\mathrm{NaCl}$ in growth environment, the relative contents of $\mathrm{Na}$ and $\mathrm{Cl}$ in tissues were higher than those at 2 weeks, respectively. In addition, $\mathrm{Cl}$ relative content remained higher than $\mathrm{Na}$ content for the same treatment and for the same organ tissue, which follows the similar trend as at 2 weeks. After 6 week treatments, $\mathrm{Na}$ relative content in leaves was 1.7, 1.6, 2.0, 1.7 , and 1.5 times of that in roots at $0,25,50,100,200 \mathrm{mM}$ $\mathrm{NaCl}$ treatments, respectively; $\mathrm{Cl}$ relative content in leaves were $2.3,1.7,1.8,2.0$, and 1.2 times of that in roots at corresponding $\mathrm{NaCl}$ treatments, respectively. These results indicated that $\mathrm{Na}$ and $\mathrm{Cl}$ were mainly distributed in leaves of potato plantlets. (Figures 3A-F).

In contrast, $\mathrm{K}$ relative content in roots, stems and leaves showed a decreasing trend with the increase of external $\mathrm{NaCl}$ concentration. Accumulation of $\mathrm{K}$ in stems was reduced, particularly in leaves. After 2 weeks of salt treatment, $\mathrm{K}$ relative content in roots was $1.1,1.3,1.3,3.0$, and 2.1 times of that in leaves at $0,25,50,100,200 \mathrm{mM} \mathrm{NaCl}$ treatments, respectively. Six weeks later, $\mathrm{K}$ relative content in roots, stems and leaves decreased compared to that at 2 weeks. $\mathrm{K}$ relative content in roots was 1.3, $1.5,1.6,2.7$, and 1.8 times of that in leaves at $0,25,50,100$, $200 \mathrm{mM} \mathrm{NaCl}$ treatments, respectively (Figures 3G-I). The comparison of $\mathrm{K}$ distribution in the different parts of potato plantlets showed that salinity seriously reduced $\mathrm{K}$ allocation toward leaves.
The $\mathrm{Na} / \mathrm{K}$ ratio dramatically increased, especially in leaves after treated with various concentrations of $\mathrm{NaCl}$. After 2 weeks of treatments, $\mathrm{Na} / \mathrm{K}$ ratio significantly increased by $2.0,4.3,6.0$, and 19.0 times in roots, 1, 2, 3.1, and 5.1 times in stems, and $1.6,2.6,8.9$, and 12.1 times in leaves, at 25, 50, 100, $200 \mathrm{mM}$ $\mathrm{NaCl}$ treatments, respectively, compared to that in control tissues, After 6-week treatment, compared to the corresponding organs of control plantlets, $\mathrm{Na} / \mathrm{K}$ ratio significantly increased by $1.7,2.1$, 5.5, and 7.9 times in roots, $1.3,1,7$, and 9.1 times in stems, and $1.8,3.3,11.7$, and 9.7 times in leaves at corresponding $\mathrm{NaCl}$ treatments, respectively. Potato plantlets treated with salt for 6 weeks had higher $\mathrm{Na} / \mathrm{K}$ ratio in the relevant organs than those treated for 2 weeks except for leaf $\mathrm{Na} / \mathrm{K}$ ratio at $200 \mathrm{mM} \mathrm{NaCl}$ concentration (Figures 3J-L).

\section{EFFECTS OF SALINE STRESS ON LEAF FREE PROLINE CONTENT, CAT AND SOD ACTIVITIES AND MDA CONTENT}

Salt stress significantly increased free proline levels in leaves (Figure 4). After 2 weeks of treatment, proline content significantly increased by $1.6,1.9,3.4$, and 4.5 times at 25, 50, 100, and $200 \mathrm{mM} \mathrm{NaCl}$ treatments, respectively, compared to control $(P<0.05)$. After 6 weeks of treatments, proline significantly content increased by $0.8,3.1,4.7$, and 3.7 times, respectively $(P<$ $0.05)$. Proline content decreased significantly at $200 \mathrm{mM} \mathrm{NaCl}$ compared to that at $100 \mathrm{Mm} \mathrm{NaCl}(P<0.05)$. Leaf proline content in plantlets treated for 6 weeks by 50,100 , and $200 \mathrm{mM} \mathrm{NaCl}$ was significant higher than that in plantlets treated for 2 weeks $(P<0.05)$.

Salt stress increased the activity of the antioxidant enzymes. After 2 week treatment, compared to control, CAT activity significantly increased by $28.9,57.9,96.8$, and $63.4 \%$ at $25,50,100$, and $200 \mathrm{mM} \mathrm{NaCl}$, respectively; while SOD activity significantly increased by $18.6,41.2,38.4$, and $52.9 \%$, respectively $(P<0.05)$. After 6 weeks, CAT and SOD activities significantly increased by $50.0,80.5,102.6$, and $13.6 \%$, and $13.1,29.5,29.6$, and $23.9 \%$ at 25 , 50,100 , and $200 \mathrm{mM} \mathrm{NaCl}$, respectively, compared to corresponding control $(P<0.05)$. Leaf CAT activity in plantlets treated with $200 \mathrm{mM} \mathrm{NaCl}$ for 2 and 6 weeks and SOD activity for 6 weeks decreased significantly compared to that in plantlets treated with $100 \mathrm{mM} \mathrm{NaCl}(P<0.05)$. Also, activities of leaf CAT and SOD in plantlets treated for 6 weeks were significantly higher than those in plantlets treated for 2 weeks except for $200 \mathrm{mM} \mathrm{NaCl}$ treatment $(P<0.05)$ (Figure 5).

Leaf MDA content was used as an indicator of oxidative damage by salt stresses. After 2 week treatment, MDA content significantly increased by $0.8,1.0,1.8$, and 2.0 times with the increase of external $\mathrm{NaCl}$ concentration compared to control plantlets; after 6 week treatment, MDA content sharply increased by 0.7 , $1.1,1.7$, and 2.4 times with the increase of salinity $(P<0.05)$. Leaf MDA content in plantlets treated for 6 weeks were significantly higher than that in plantlets treated for 2 weeks $(P<0.05)$ (Figure 6).

\section{EFFECTS OF SALINITY STRESS ON LEAF STOMATAL AREA AND CHLOROPHYLL CONTENT}

Two weeks of salt treatment reduced stomatal area significantly by $18.0,35.4,61.5$, and $86.7 \%$ at $25,50,100$, and $200 \mathrm{mM} \mathrm{NaCl}$ 

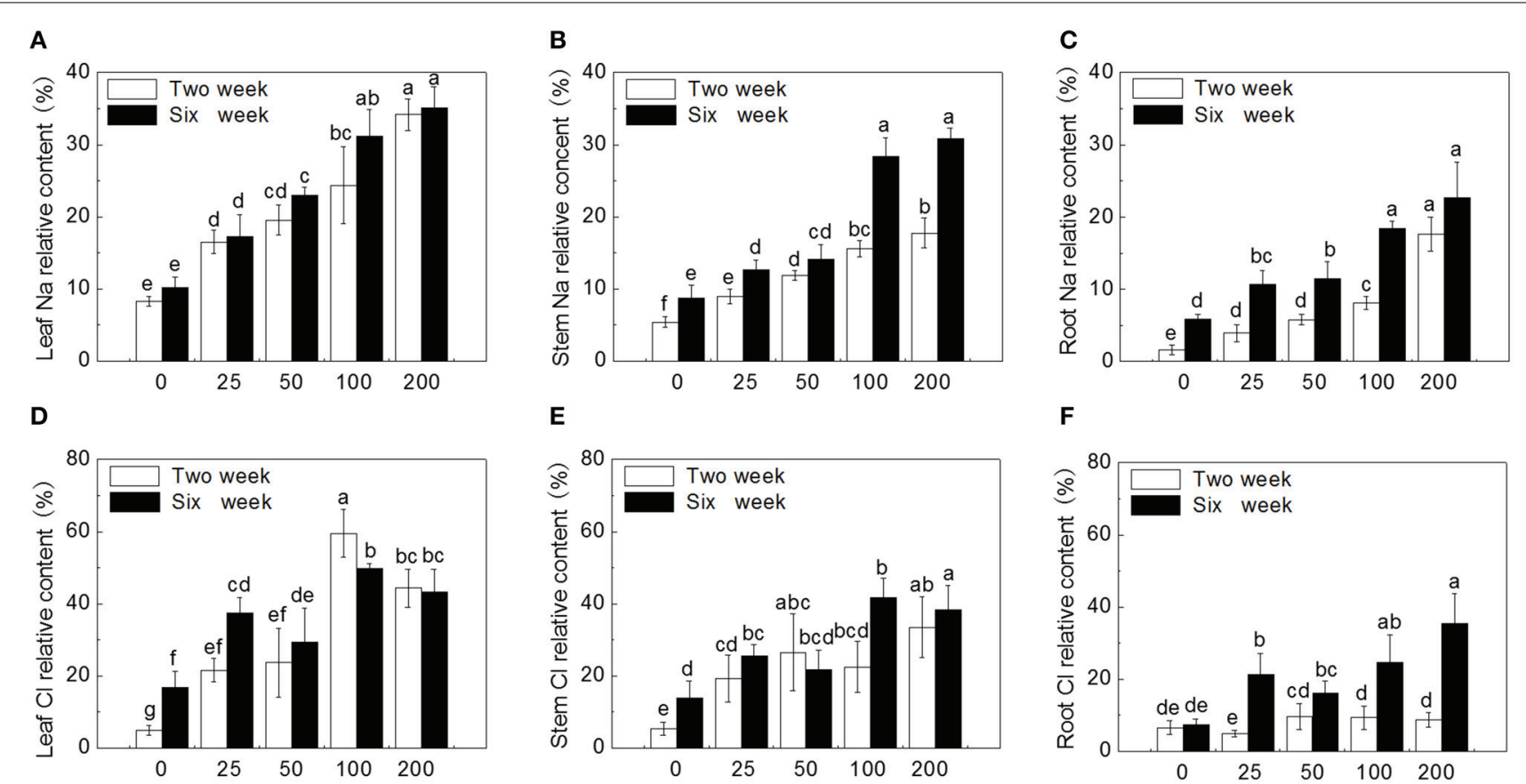

G

H

I
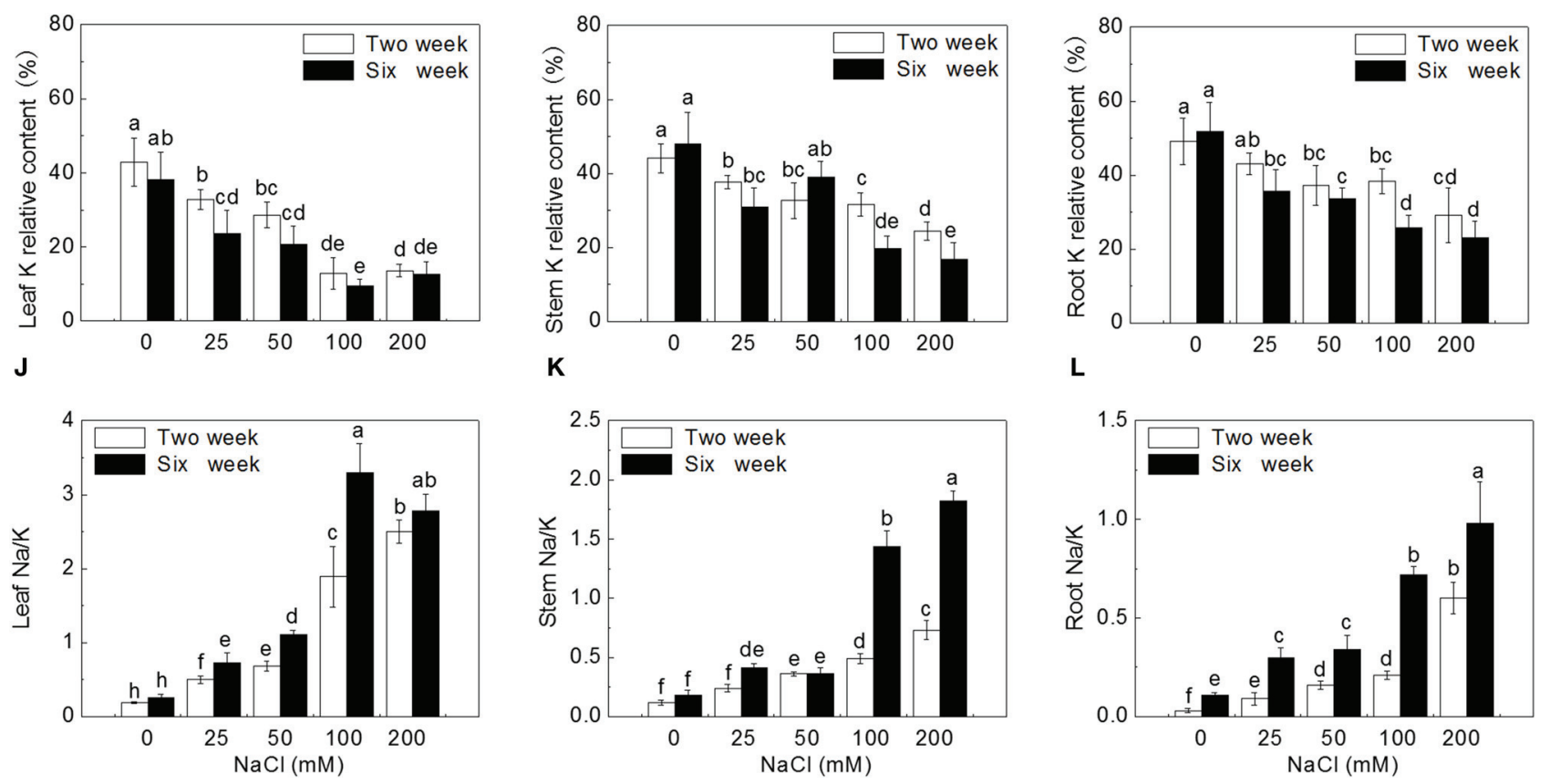

FIGURE 3 | Ion relative content and $\mathrm{Na} / \mathrm{K}$ ratio under different concentrations of $\mathrm{NaCl}$ using SEM-EDS. (A) Leaf $\mathrm{Na}$ relative content, (B) stem $\mathrm{Na}$ relative content, (C) root $\mathrm{Na}$ relative content, (D) leaf $\mathrm{Cl}$ relative content, (E) stem $\mathrm{Cl}$ relative content, (F) root $\mathrm{Cl}$ relative content, (G) leaf $\mathrm{K}$ relative content, (H) stem $\mathrm{K}$ relative content, (I) root $\mathrm{K}$ relative content, (J) ratio of $\mathrm{Na}$ to $\mathrm{K}$ in leaf, (K) ratio of $\mathrm{Na}$ to $\mathrm{K}$ in stem, (L) ratio of $\mathrm{Na}$ to $\mathrm{K}$ in root. Values are means and bars indicate SDs $(n=6)$. Columns with different letters indicate significant difference by Duncan's multiple range tests at $P<0.05$ (Duncan test). concentrations, respectively, compared to control $(P<0.05)$. Six weeks of salt treatment dramatically reduced stomatal area by $70.3,88.2,91.6$, and $99.4 \%$ with the increase of $\mathrm{NaCl}$ concentration $(P<0.05)$. Stoma was almost closed after 6 weeks of $200 \mathrm{mM} \mathrm{NaCl}$ treatment (Figure 7A).
The trend of changes for chlorophyll content was similar to that for stomatal area. After 2 weeks of salt treatment, leaf chlorophyll content decreased gradually by $24.8,44.2,65.5$, and $70.8 \%$ with the increase of $\mathrm{NaCl}$ concentration, compared to control $(P<0.05)$. After 6 weeks of salt treatment, chlorophyll 
content sharply decreased by 33.9, 68.3, 88.1, and 93.6\% with the increase of $\mathrm{NaCl}$ concentration $(P<0.05)$, and was much lower than that at 2 weeks under corresponding salt stresses (Figure 7B).

At the whole plantlet level, $\mathrm{NaCl}$ treatments inhibited potato plantlet growth. The height of seedlings gradually decreased with increase of external $\mathrm{NaCl}$ concentration. After 6 weeks of treatment, severe salt stress $(200 \mathrm{mM} \mathrm{NaCl})$ induced a greater decline in shoot growth and root development of potato plantlets (Figure S1).

\section{DISCUSSION}

\section{SALINITY INDUCED ULTRASTRUCTURAL CHANGES OF LEAF} MESOPHYLL CELLS AND CHLOROPLASTS

In present study, high levels of $\mathrm{Na}$ and $\mathrm{Cl}$, and low level of $\mathrm{K}$ were distributed in leaves. The changes in chemical contents could result in ultrastructural alteration in leaf cells. Three

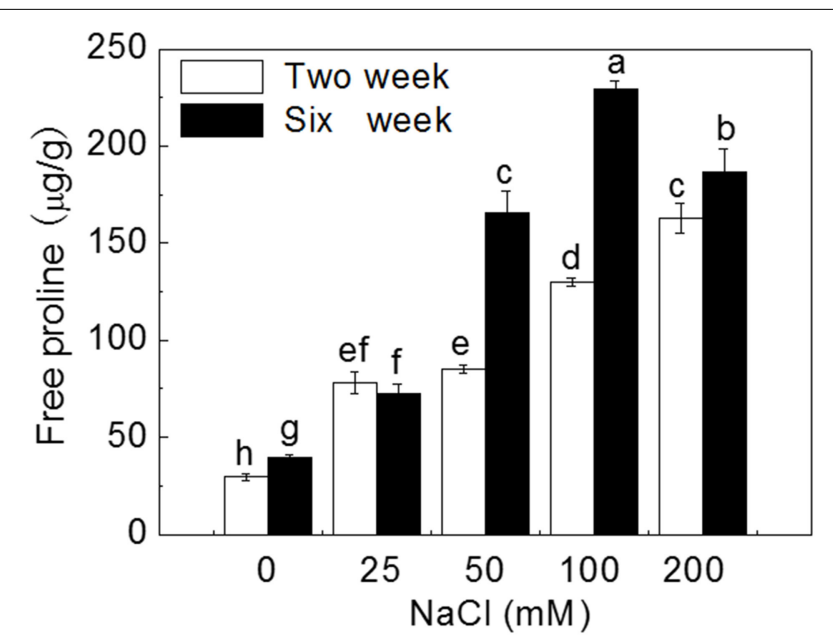

FIGURE 4 | Effects of $\mathrm{NaCl}$ treatment on free proline content. Values are means and bars indicate SDs $(n=6)$. Columns with different letters indicate significant difference by Duncan's multiple range tests at $P<0.05$. salt-stress related alterations were observed. Firstly, the number of chloroplasts displaying swelled and distorted thylakoids decreased, accompanied by chloroplasts moving to the cell center. This chloroplast change is a typical effect of salinity as previously observed in salt-stressed Cucumis sativus L. (Shu et al., 2013). Secondly, cell walls thickened and plasmolysis occurred and the intercellular spaces of cell decreased with the increase of external salt concentration, which was also reported in potato cultivars (Bruns and Hecht-Buchholz, 1990; Navarro et al., 2007). Thirdly, lamella became disordered, loosened, and even indistinct, with reduced grana stacking because of inhibition of protein synthesis. Krzesłowska (2010) has reported that thickened cell wall could be as a barrier, protecting cell from toxicity of trace metals. So cell wall may function and limit passive $\mathrm{Na}$ and $\mathrm{Cl}$ enter into protoplast, maintaining structural integrity of the cell in the early low salt stress. It has been known salt stress can lead to osmotic

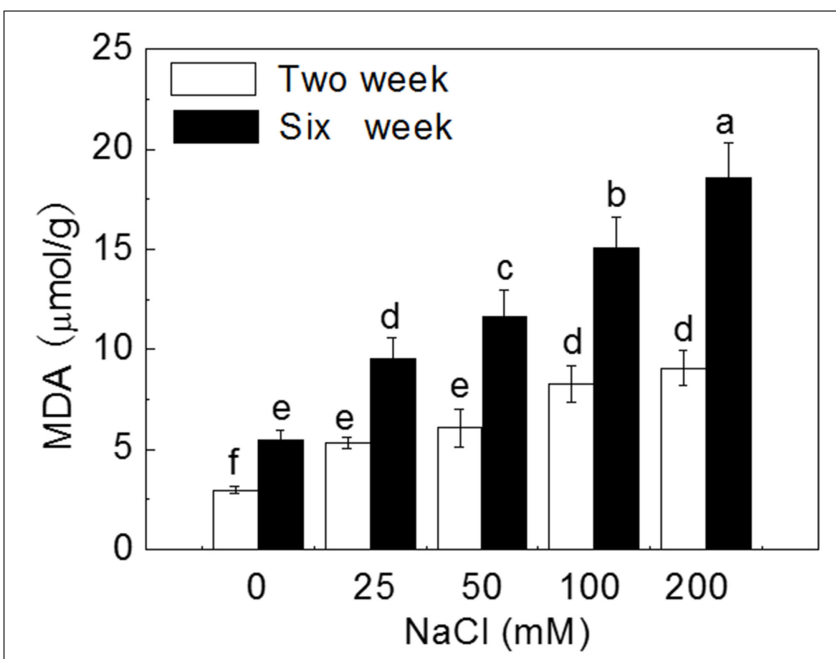

FIGURE 6 | Effects of $\mathrm{NaCl}$ treatment on malondialdehyde (MDA) content. Values are means and bars indicate SDs $(n=6)$. Columns with different letters indicate significant difference by Duncan's multiple range tests at $P<0.05$.
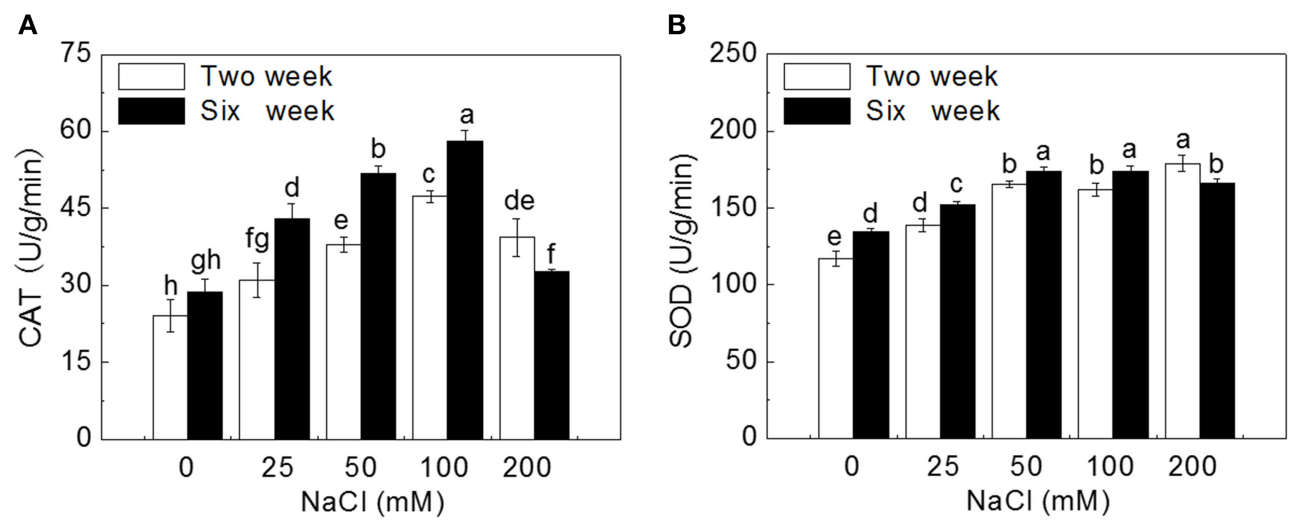

FIGURE 5 | Effects of $\mathbf{N a C l}$ treatment on activities of catalase (CAT) and superoxide dismutase (SOD). (A) CAT activity, (B) SOD activity. Values are means and bars indicate SDs $(n=6)$. Columns with different letters indicate significant difference by Duncan's multiple range tests at $P<0.05$. 

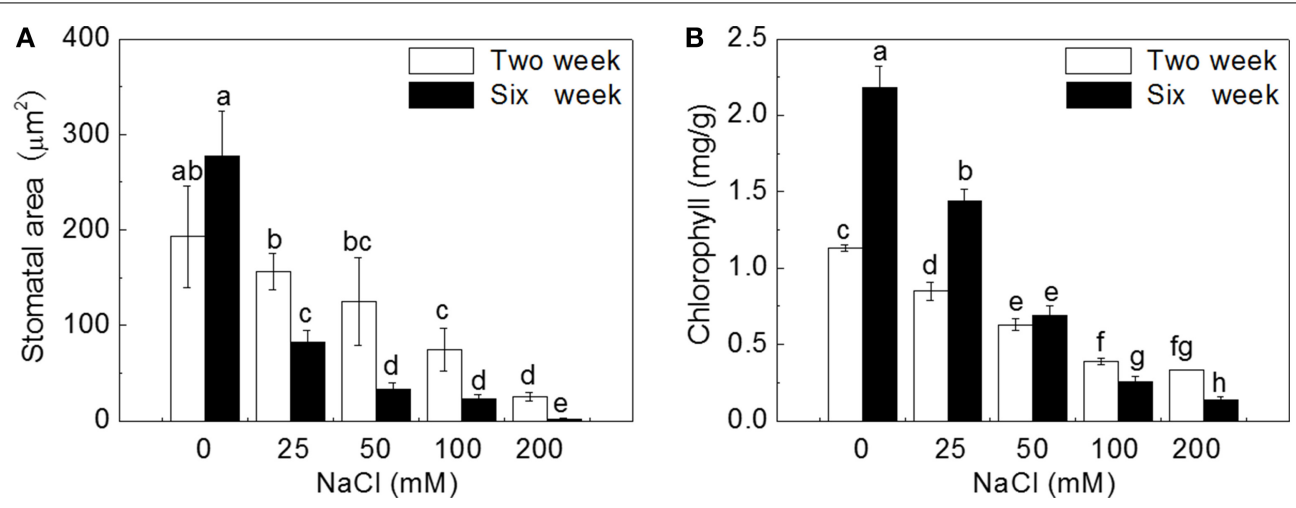

FIGURE 7 | Effects of $\mathbf{N a C l}$ treatment on stomatal area (A) and chlorophyll content (B). Values are means and bars indicate SDs ( $n=6)$. Columns with different letters indicate significant difference by Duncan's multiple range tests at $P<0.05$.

damage. $\mathrm{Na}^{+}$could be used directly for osmotic adjustment to maintain cell turgor and photosynthetic activity under low external salt concentration (Yousfi et al., 2010; Ebrahimi and Bhatla, 2012; Ma et al., 2012). However, with the increase of salt levels ( $\mathrm{NaCl}$ concentration $>50 \mathrm{mM}$ ), high concentrations of $\mathrm{Na}$ and $\mathrm{Cl}$ accumulated in leaf apoplast, leading to water loss of cell, plasmolysis and decrease of intercellular spaces in the leaves of potato plantlets. The present study observed invaginated membrane system forming numerous vesicles under salt treatments supporting observations by Kim and Park (2010), whilst contrary to Queirós et al. (2011) in which no vesicle was found in salt-adapted potato cell line. Vacuolation may be a response to membrane system damage induced by ROS caused by toxicity of $\mathrm{Na}$ and $\mathrm{Cl}$ (Kim and Park, 2010). ROS lead to the increase of plasma membrane permeability and extravasations of soluble substances, causing osmotic water imbalance, aggravating plasmolysis. Since membrane vesicles have $\mathrm{Na}^{+} / \mathrm{H}^{+}$antiporter (Blumwald et al., 2000) and cell can sequester ion into vacuole (Kim and Park, 2010), vesicles may compartmentalize $\mathrm{Na}$ and $\mathrm{Cl}$ and migrate to walls. When plants were exposed to high $\mathrm{NaCl}$ concentration $(100 \mathrm{mM})$, membrane disappeared. Salt inhibits absorption of $\mathrm{Ca}^{2+}$, further leading to instability of cell membrane and cell wall. Integral of membrane is essential in ions absorption and distribution. The destruction of the membrane structure inevitably disrupted ion homeostasis, affecting osmotic potential and inducing ion toxicity.

Disorganization of whole cells was accompanied by disintegrated chloroplasts having more starch and dissolved stroma lamella under $200 \mathrm{mM} \mathrm{NaCl}$. It was speculated that starch synthesis plays a role in lessening the hyperosmotic stress as osmoticum. A total disorganization of the protoplast in callus cells was reported in other plants, possibly caused by dehydration (Bennici and Tani, 2012). Disintegration of chloroplasts and mesophyll cells end the photosynthesis, thus, maintaining structural integrity is necessary in plant growth (Bennici and Tani, 2012).

\section{SALINITY CHANGED ION HOMEOSTASIS IN POTATO PLANTLETS}

It has been known that the total $\mathrm{Na}^{+}$and $\mathrm{Cl}^{-}$content increased under salt in potato cell line, and $\mathrm{K}^{+} / \mathrm{Na}^{+}$ratio was a little higher in the adapted line (Queirós et al., 2011). Ruan et al. (2005) showed that $\mathrm{Na}^{+}$accumulation decreased from the roots to leaves in Kosteletzkya virginica. Higher $\mathrm{Na}^{+}$distributed in roots than in leaves in maize under salt stress (Azevedo-Neto and Prisco, 2004). In Capsicum chinense, more $\mathrm{Na}^{+}$was restricted in roots (Bojorquez-quintal et al., 2014). Higher levels of $\mathrm{Na}^{+}$in roots can maintain the normal osmotic potential and prevent it from being transported to the leaves, therefore avoiding the accumulation of $\mathrm{Na}^{+}$in the leaves (Tester and Davenport, 2003; Munns and Tester, 2008; Xue et al., 2013). Queirós et al. (2009) reported that higher $\mathrm{Na}^{+}$distributed in roots, inhibiting $\mathrm{Na}^{+}$transport to leaves in potato cell. In present study, the distribution of $\mathrm{Na}$ and $\mathrm{Cl}$ increased from roots to stems and leaves in potato plantlets, indicating that potato is not a salt exclusion plant and has lower capacity to retain saline ions in their roots. High ions in leaves leaded to osmotic damage and oxidative stress, affecting physiological and biochemical metabolism. In addition, as a whole more $\mathrm{Cl}$ accumulated in potato tissue than $\mathrm{Na}$, indicating the absorption of $\mathrm{Cl}^{-}$was higher than $\mathrm{Na}$, which is similar to the findings in sunflower (Ebrahimi and Bhatla, 2011) and in Clions (Greenway and Munns, 1980). Higher $\mathrm{Cl}^{-}$accumulation lead to more serious and instant damage under salt stress (Yao and Fang, 2008). In our study, the absorption of $\mathrm{Na}$ and $\mathrm{Cl}$ in roots, stems and leaves of potato plantlet was enhanced with the increases of $\mathrm{NaCl}$ concentration, and the relative contents of $\mathrm{Na}$ and $\mathrm{Cl}$ were the highest in leaves, and lowest in roots.

$\mathrm{K}^{+}$participates in many cellular functions, such as protein synthesis, enzyme activation and osmotic regulation (Peng et al., 2004; Takahashi et al., 2007; Amtmann et al., 2008). Therefore, the regulation of $\mathrm{K}^{+}$homeostasis plays a critical role in plant tolerance to abiotic stresses (Ashley et al., 2006; Wang and Wu, 2010; Demidchik, 2014; Anschütz et al., 2014; Shabala and Pottosin, 2014). Salinity induced plant nutritional disorders, such as the suppression of $\mathrm{K}^{+}$uptake (Kader and Lindberg, 2005; Kronzucker et al., 2006; Shabala and Cuin, 2008). Bojorquez-quintal et al. (2014) suggested that more $\mathrm{K}^{+}$accumulated in roots is correlated with the salt tolerance of Capsicum chinense. In present study, salt stress dramatically reduced $\mathrm{K}^{+}$uptake and accumulation, especially in leaves, resulting in increased $\mathrm{Na} / \mathrm{K}$ ratio in all tissues with the increase of external salt concentration and the duration of treatments. 


\section{PHYSIOLOGICAL MECHANISM OF POTATO PLANTLETS ADAPTING TO GRADIENT SALINE STRESS}

Salinity leads to physiological changes in plant, especially osmotic and oxidative stress (Zhang and Shi, 2013). The accumulation of osmoprotectants is important for plant to adapt to osmotic stress (Apse and Blumwald, 2002; Waditee et al., 2007; Chan et al., 2011; Rivero et al., 2014). Proline, an important compatible osmolyte in plants, could maintain cell turgor and function in osmotic adjustment to improve plant tolerance to osmotic stress (Abrahám et al., 2010; Huang et al., 2013). In many plants, the accumulation of proline could lead to salt tolerance and has even been used as an important trait in selecting tolerant species or genotypes (Ashraf and Harris, 2004; Khelil et al., 2007; Ruffino et al., 2010). Recently, Bojorquez-quintal et al. (2014) found that more proline was accumulated in leaves of salt-tolerant habanero pepper (Capsicum chinense Jacq.) cultivar (Rex) than in salt-sensitive one (ChichenItza) under $150 \mathrm{mM} \mathrm{NaCl}$ treatment. In our study, the levels of free proline increased significantly with the increase of external salt concentration and with the duration of treatments except for a little decline at $200 \mathrm{mM} \mathrm{NaCl}$ after 6-week treatment (Figure 3). The reason may be that $200 \mathrm{mM}$ induced excessive damage to plant cells and inhibited proline synthesis.

Antioxidant enzymes in plant can remove ROS and alleviate oxidative damage (Krantev et al., 2008; Mishra et al., 2011). It has been known that the higher activities of CAT and SOD could improve plant tolerance to salinity and $\mathrm{K}^{+}$-deficiency conditions (Wang et al., 2010; Zhou et al., 2014). It was found that SOD activity was significantly higher in the leaves of salttolerant wild tomato (Lycopersicon pennellii) than that of saltsensitive cultivated tomato (Lycopersicon esculentum) after 12 and $84 \mathrm{~d}$ of salt treatment $(140 \mathrm{mM} \mathrm{NaCl})$ (Koca et al., 2006). Similarly, salt-tolerant Plantago maritima showed a better protection mechanism against oxidative damage caused by salt stress by its higher induced activities of CAT, SOD, glutathione reductase (GR) and peroxidase (POX) than the salt-sensitive $P$. media (Sekmen et al., 2007). Co-expression of the Suaeda salsa CAT and glutathione S-transferase (GST) genes enhanced the active oxygen-scavenging system that led to improved salt tolernace in transgenic rice, resulting from not only increased CAT and GST activities but also the combined increase in SOD activity (Zhao and Zhang, 2006). Jing et al. (2014) reported that overexpression of mangrove (Kandelia candel) copper/zinc superoxide dismutase gene $(K c C S D)$ enhanced salinity tolerance in tobacco: $K c C S D$ transgenic lines were more $\mathrm{Na}^{+}$tolerant than wild-type (WT) tobacco in terms of lipid peroxidation, root growth, and survival rate; $\mathrm{Na}^{+}$injury to chloroplast was less pronounced in transgenic tobacco plants due to enhanced SOD activity by an increment in SOD isoenzymes under $100 \mathrm{mM} \mathrm{NaCl}$ stress from $24 \mathrm{~h}$ to $7 \mathrm{~d}$; catalase activity rose in KcCSD overexpressing tobacco plants and transgenic plants better scavenged $\mathrm{NaCl}$-elicited ROS compared to WT ones. In present study, the activities of CAT and SOD in leaves of potato plantlets significantly increased with the increase of $\mathrm{NaCl}$ concentration $(0 \sim 100 \mathrm{mM})$ in medium. When exposed to $200 \mathrm{mM} \mathrm{NaCl}$, especially after 6 weeks, leaf cells were severely damaged, even disorganized (Figure 1), leading to the damage of cellular structure or alterations of metabolism, and reducing the synthesis of CAT and SOD.
Soil salinity is known to increase the level of ROS in plant leaves and MDA is a major product of membrane lipid peroxidation (Mittova et al., 2004; Koca et al., 2006; Yazici et al., 2007). Therefore, leaf MDA content could represent the degree of cell membrane damage and is usually used to evaluate plant salt tolerance (Luna et al., 2000; Miao et al., 2010; Han et al., 2014). In our study, leaf MDA content increased significantly with the increase of external salt concentration after 2-week treatment and even increased more rapidly after 6-week treatment. However, the activities of SOD and CAT may not enough to eliminate ROS, resulted in large production of MDA under higher salt stress $(200 \mathrm{mM})$.

\section{SALINITY REDUCED LEAF STOMATAL AREA AND CHLOROPHYLL CONTENT}

Chlorophyll is essential for photosynthesis, and the increase of chlorophyll content can reflect the increase of photosynthetic activity (Yamori et al., 2006). Ben et al. (2010) and $\mathrm{Su}$ et al. (2011) suggested that the accumulation of chlorophyll content could enhance plant salt tolerance. In the present study, leaf chlorophyll content gradually decreased with the increase of $\mathrm{NaCl}$ treatment and duration, which could result from the inhibition of chlorophyll synthesis caused by chloroplast damage.

Gas exchange through stoma play important role in carbon assimilation (Wilkinson and Davies, 2002). Salt stress decreases leaf stomatal area by reducing leaf water content and leaf turgor induced by ABA signal (Wilkinson and Davies, 2002). Therefore, stomatal conductance was correlated to salinity stress (Liu et al., 2014b). In our study, salt stress seriously induced stomatal closure. Reduced $\mathrm{CO}_{2}$ diffusion caused by stomatal closure lead to suppression of photosynthesis, affecting plant growth (Figure S1).

In conclusion, the adaptation of plants to salt stress is a complex process at cellular, biochemical and physiological levels. In the present study, several parameters were analyzed to demonstrate ultrastructural and physiological responding mechanisms of potato (Solanum tuberosum L.) plantlets to gradient saline stress (Figure 8). We found that with the increase of external $\mathrm{NaCl}$ concentration and the duration of treatments, the number of chloroplasts and cell intercellular space markedly decreased, cell wall thickened and even ruptured, and mesophyll cells and chloroplasts were gradually damaged to a complete disorganization. Above ultrastructural changes may be induced by the increased concentrations of $\mathrm{Na}^{+}$that was transported into cytosol probably through non-selective cation channels (NSCCs), high-affinity $\mathrm{K}^{+}$transporters (HKTs, probably HKT1;2; HKT1;4; HKT1;5 and HKT2;1) and permeated directly across plasma membrane, and $\mathrm{Cl}^{-}$that was probably transported by cation- $\mathrm{Cl}^{-}$cotransporter (CCC) (Apse and Blumwald, 2007; Plett and Moller, 2010; Zhang et al., 2010; Zhang and Shi, 2013; Almeida et al., 2014a,b; Maathuis, 2014; Maathuis et al., 2014). More and more $\mathrm{K}^{+}$was probably transported out of the cell by $\mathrm{K}^{+}$outward-rectifying channels (KORs) activated by membrane depolarization (DPZ) (Chen et al., 2007; Sun et al., 2009; Lu et al., 2013; Demidchik, 2014; Demidchik et al., 2014; Lai et al., 2014). Leaf MDA content increased significantly 

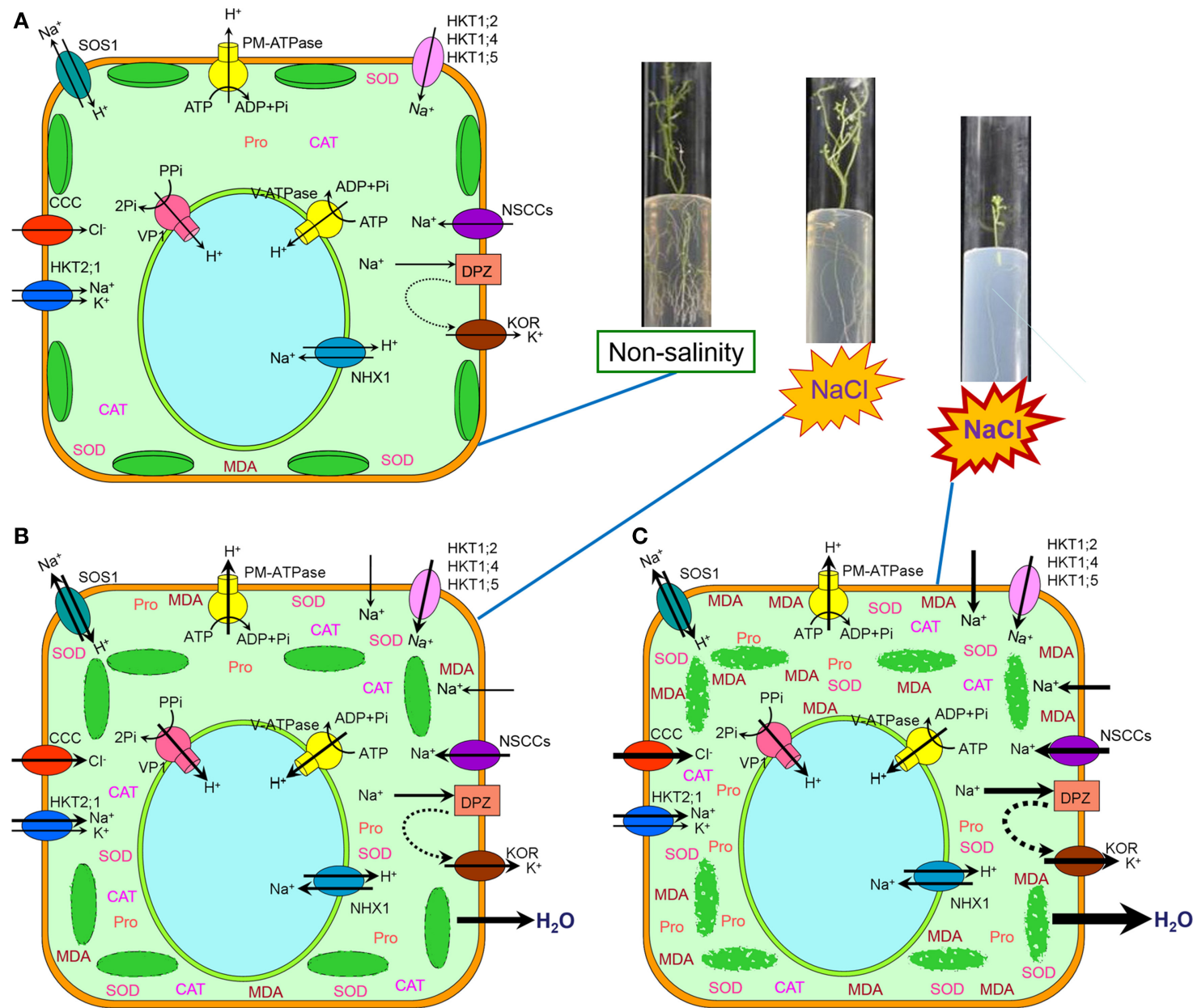

FIGURE 8 | Schematic model of ultrastructural and physiological responding mechanisms of the mesophyll cells from potato (Solanum tuberosum L.) plantlets to gradient saline stress. (A) Under non-salinity condition, water and ions was maintained at a balance status, only little proline (Pro), CAT, SOD, and MDA were accumulated within cytosol, and integrated chloroplasts were closely arranged along plasma membrane. (B) Under moderate salinity condition, abundant $\mathrm{Na}^{+}$was transported into cytosol probably through non-selective cation channels (NSCCs), high-affinity $\mathrm{K}^{+}$transporters (HKTs, probably HKT1;2, HKT1;4, HKT1;5, and HKT2;1) and a little permeated directly across plasma membrane, and $\mathrm{Cl}^{-}$was probably transported by cation- $\mathrm{Cl}^{-}$cotransporter (CCC). Some $\mathrm{K}^{+}$was transported out of the cell by $\mathrm{K}^{+}$outward-rectifying channels (KORs) activated by membrane depolarization (DPZ). The membrane system was damaged resulting in the increase of MDA and damaged chloroplasts were not closely arranged along plasma membrane. Stoma closed because of water loss and chlorophyll content decreased because of chloroplast damage. For adaptation to moderate salinity, $\mathrm{Na}^{+}$efflux or extrusion by plasma membrane $\mathrm{Na}+\mathrm{H}^{+}$ antiporter (salt overly sensitive, SOS1) motivated by plasma membrane
ATPase (PM-ATPase) and vacuolar $\mathrm{Na}^{+}$compartmentation by tonoplast $\mathrm{Na}^{+} / \mathrm{H}^{+}$antiporter (NHX1) motivated by vacuolar ATPase (V-ATPase) and $\mathrm{H}^{+}$-pyrophosphatase (VP1) functioned to reduce $\mathrm{Na}^{+}$toxicity in cytosol, at the same time osmoprotectants such as proline were accumulated and the activities of antioxidant enzymes (CAT and SOD) increased. (C) Under high salinity condition, more and more $\mathrm{Na}^{+}$was transported into cytosol probably through NSCCs and permeated directly across plasma membrane although the amount of $\mathrm{Na}^{+}$transported by HKTs did not increase, and more $\mathrm{Cl}^{-}$was probably transported by CCC. More and more $\mathrm{K}^{+}$was transported out of the cell by KOR. The membrane system was seriously damaged resulting in the rapid increase of MDA and disintegrated chloroplasts appeared. Stoma closed completely because of increasing water loss and chlorophyll content decreased dramatically because of severe chloroplast damage. However, the ability of $\mathrm{Na}^{+}$efflux or extrusion by SOS1 and vacuolar $\mathrm{Na}^{+}$

compartmentation by $\mathrm{NHX} 1$ were not enhanced because of serious damage to membrane system, at the same time osmoprotectant content and the activities of antioxidant enzymes (CAT and SOD) did not increased any more, but even decreased. Therefore, the growth of potato plantlets was inhibited. due to all membrane lipid peroxidation induced by increasing and continuous salt stress, which also induced stomata closure and chlorophyll content decline. Potato plantlets showed adaptation ability to moderate salt stress through $\mathrm{Na}^{+}$efflux or extrusion by plasma membrane $\mathrm{Na}^{+} / \mathrm{H}^{+}$antiporter (salt overly sensitive, SOS1) motivated by plasma membrane ATPase (PMATPase), vacuolar $\mathrm{Na}^{+}$compartmentation by tonoplast $\mathrm{Na}^{+} / \mathrm{H}^{+}$ antiporter (NHX1) driven by vacuolar ATPase (V-ATPase) and $\mathrm{H}^{+}$-pyrophosphatase (VP1), accumulating osmoprotectants such as proline, and improving the activities of antioxidant enzymes (CAT and SOD). This work provided both anatomical and physiological data for characterization of damages induced by salinity and the method could be used for selecting salt-tolerant potato cultivars. 


\section{ACKNOWLEDGMENTS}

This research was supported by Program for Changjiang Scholars and Innovative Research Team in University (IRT13019), International Science \& Technology Cooperation Program of China (2014DFG31570), Gansu S\&T Foundation (1308RJZA131 and 1308RJIA005), Lanzhou S\&T Research Project (2013-4-156 and GSCS-2012-04) and NSFC (31222053).

\section{SUPPLEMENTARY MATERIAL}

The Supplementary Material for this article can be found online at: http://www.frontiersin.org/journal/10.3389/fpls.2014. 00787/abstract

Figure S1 | Growth of potato plantlets in MS agar plates. Plantlets grown on MS were transferred to new solid agar MS supplemented with various concentrations of $\mathrm{NaCl}(0,25,50,100$, and $200 \mathrm{mM})$ for 2 and 6 weeks, respectively.

\section{REFERENCES}

Abdullahil-Baque, M., Lee, E., j., Paek, K. Y., Ashley, M. K., and Grabov, A. (2010). Medium salt strength induced changes in growth, physiology and secondary metabolite content in adventitious roots of Morinda citrifolia: the role of antioxidant enzymes and phenylalanine amMonia lyase. Plant Cell Rep. 29, 685-694. doi: 10.1007/s00299-010-0854-4

Abrahám, E., Hourton-Cabassa, C., Erdei, L., and Szabados, L. (2010). Methods for determination of proline in plants. Methods Mol. Biol. 639, 317-331. doi: 10.1007/978-1-60761-702-0_20

Almeida, P. M., de Boer, G. J., and de Boer, A. H. (2014a). Assessment of natural variation in the first pore domain of the tomato HKT1;2 transporter and characterization of mutated versions of SlHKT1;2 expressed in Xenopus laevis oocytes and via complementation of the salt sensitive athkt1;1 mutant. Front. Plant Sci. 5:600. doi: 10.3389/fpls.2014.00600

Almeida, P., de Boer, G.-J., and de Boer, A. H. (2014b). Differences in shoot $\mathrm{Na}^{+}$accumulation between two tomato species are due to differences in ion affinity of HKT1;2. J. Plant Physiol. 171, 438-447. doi: 10.1016/j.jplph.2013. 12.001

Amtmann, A., Troufflard, S., and Armengaud, P. (2008). The effect of potassium nutrition on pest and disease resistance in plants. Physiol. Plant. 133, 682-691. doi: 10.1111/j.1399-3054.2008.01075.x

Anschütz, U., Becker, D., and Shabala, S. (2014). Going beyond nutrition: regulation of potassium homoeostasis as a common denominator of plant adaptive responses to environment. J. Plant Physiol. 171, 670-687. doi: 10.1016/j.jplph.2014.01.009

Apse, M. P., and Blumwald, E. (2002). Engineering salt tolerance in plants. Curr. Opin. Biotechnol. 13, 146-150. doi: 10.1016/S0958-1669(02)00298-7

Apse, M. P., and Blumwald, E. (2007). $\mathrm{Na}^{+}$transport in plants. FEBS Lett. 581, 2247-2254. doi: 10.1016/j.febslet.2007.04.014

Arbona, V., Hossain, Z., López-Climent, M. F., Pérez-Clemente, R. M., and Gómez Cadenas, A. (2008). Antioxidant enzymatic activity is linked to waterlogging stress tolerance in citrus. Physiol. Plant. 132, 452-466. doi: 10.1111/j.13993054.2007.01029.x

Arnon, D. I. (1949). Copper enzymes in isolated chloroplasts. Plant Physiol. 24, 1-15. doi: 10.1104/pp.24.1.1

Ashley, M. K., Grant, M., and Grabov, A. (2006). Plant responses to potassium deficiencies: a role for potassium transport proteins. J. Exp. Bot. 57, 425-436. doi: $10.1093 / \mathrm{jxb} / \mathrm{erj} 034$

Ashraf, M., and Harris, P. J. C. (2004). Potential biochemical indicators of salinity tolerance in plants. Plant Sci. 166, 3-16. doi: 10.1016/j.plantsci.2003. 10.024

Azevedo-Neto, A. D., and Prisco, J. T. (2004). Effects of salt stress on plant growth, stomatal response and solute accumulation of different maize genotypes. Braz. J. Plant Physiol. 16, 31-38. doi: 10.1590/s1677-04202004000100005

Ben, A. C., Ben, R. B., Sensoy, S., Boukhriss, M., and Ben, A. F. (2010). Exogenous proline effects on photosynthetic performance and antioxidant defense system of young olive tree. J. Agric. Food Chem. 58, 4216-4222. doi: 10.1021/jf90 41479
Ben-Amor, N., Megdiche, W., Jiménez, A., Sevilla, F., and Abdelly, C. (2010). The effect of calcium on the antioxidant systems in the halophyte Cakile maritima under salt stress. Acta Physiol. Plant. 32, 453-461. doi: 10.1007/s11738-009$0420-2$

Bennici, A., and Tani, C. (2009). Ultrastructural effects of salinity in Nicotiana bigelovii var. bigelovii callus cells and Allium cepa roots. Caryologia 62, 124-133. doi: 10.1080/00087114.2004.10589677

Bennici, A., and Tani, C. (2012). Ultrastructural characteristics of callus cells of Nicotiana tabacum L. var. BELW3 grown in presence of $\mathrm{NaCl}$. Caryologia 65, 72-81. doi: $10.1080 / 00087114.2012 .678091$

Blumwald, E., Aharon, G. S., and Apse, M. P. (2000). Sodium transport in plant cells. Biochim. Biophys. Acta 1465, 140-151. doi: 10.1016/S00052736citation(00)00135-8

Bojorquez-quintal, J., Velarde, A., Ku, A., Carrillo, M., Ortega, D., Echevarria, I., et al. (2014). Mechanisms of salt tolerance in habanero pepper plants (Capsicum chinense Jacq.): proline accumulation, ions dynamics, root-shoot partition and compartmentation. Front. Plant Sci. 5:605. doi: 10.3389/fpls.2014. 00605

Bruns, S., and Hecht-Buchholz, C. (1990). Light and electron microscope studies on the leaves of several potato cultivars after application of salt at various development stages. Potato Res. 33, 33-41. doi: 10.1007/BF02358128

Cabot, C., Sibole, J. V., Barceló, J., and Poschenrieder, C. (2014). Lesson from crop plants struggling with salinity. Plant Sci. 226, 2-13. doi: 10.1016/j.plantsci.2014.04.013

Carden, D. E., Walker, D. J., Flowers, T. J., and Miller, A. J. (2003). Single-cell measurements of the contributions of cytosolic $\mathrm{Na}^{+}$and $\mathrm{K}^{+}$to salt tolerance. Plant Physiol. 131, 676-683. doi: 10.1104/pp.011445

Chan, Z., Grumet, R., and Loescher, W. (2011). Global gene expression analysis of transgenic, mannitol-producing, and salt-tolerant Arabidopsis thaliana indicates widespread changes in abiotic and biotic stress-related genes. J. Exp. Bot. 62, 4787-4803. doi: 10.1093/jxb/err130

Chen, Z., Pottosin, I. I., Cuin, T. A., Fuglsang, A. T., Tester, M., Jha, D., et al. (2007). Root plasma membrane transporters controlling $\mathrm{K}^{+} / \mathrm{Na}^{+}$homeostasis in salt-stressed barley. Plant Physiol. 145, 1714-1725. doi: 10.1104/pp.107. 110262

Cho, K., Kim, Y. C., Woo, J. C., Rakwal, R., Agrawal, G. K., Yoeun, S., et al. (2012). Transgenic expression of dual positional maize lipoxygenase-1 leads to the regulation of defense-related signaling molecules and activation of the antioxidative enzyme system in rice. Plant Sci. 238-245. doi: 10.1016/j.plantsci.2011. 10.016

Csiszár, J., Gallé, A., Horváth, E., Dancsó, P., Gombos, M., Váry, Z., et al. (2012). Different peroxidase activities and expression of abiotic stress-related peroxidases in apical root segments of wheat genotypes with different drought stress tolerance under osmotic stress. Plant Physiol. Biochem. 52, 119-129. doi: 10.1016/j.plaphy.2011.12.006

Daneshmand, F., Arvin, M., and Kalantari, K. (2010). Physiological responses to $\mathrm{NaCl}$ stress in three wild species of potato in vitro. Acta Physiol. Plant. 32, 91-101. doi: 10.1007/s11738-009-0384-2

Deinlein, U., Stephan, A. B., Horie, T., Luo, W., Xu, G., and Schroeder, J. I. (2014). Plant salt-tolerance mechanisms. Trends Plant Sci. 19, 371-379. doi: 10.1016/j.tplants.2014.02.001

Delauney, A. J., Hu, C. A., and Verma, D. P. (1992). A bifunctional enzyme (delta 1-pyrroline-5-carboxylate synthetase) catalyzes the first two steps in proline biosynthesis in plants. Proc. Natl. Acad. Sci. U.S.A. 89, 9354-9358. doi: 10.1073/pnas.89.19.9354

Demidchik, V., Straltsova, D., Medvedev, S. S., Pozhvanov, G. A., Sokolik, A., and Yurin, V. (2014). Stress-induced electrolyte leakage: the role of $\mathrm{K}^{+}$-permeable channels and involvement in programmed cell death and metabolic adjustment. J. Exp. Bot. 65, 1259-1270. doi: 10.1093/jxb/eru004

Demidchik, V. (2014). Mechanism and physiological roles of $\mathrm{K}^{+}$efflux from root cells. J. Plant Physiol. 171, 696-707. doi: 10.1016/j.jplph.2014.01.015

Ebrahimi, R., and Bhatla, S. (2012). Ion distribution measured by electron probe $\mathrm{X}$-ray microanalysis in apoplastic and symplastic pathways in root cells in sunflower plants grown in saline medium. J. Bioscience. 37, 713-721. doi: 10.1007/s12038-012-9246-y

Ebrahimi, R., and Bhatla, S. C. (2011). Effect of sodium chloride levels on growth, water status, uptake, transport, and accumulation pattern of sodium and chloride Ions in young sunflower plants. Commun. Soil Sci. Plant. 42, 815-831. doi: $10.1080 / 00103624.2011 .552657$ 
Evelin, H., Giri, B., and Kapoor, R. (2012). Contribution of Glomus intraradices inoculation to nutrient acquisition and mitigation of ionic imbalance in NaCl-stressed Trigonella foenum-graecum. Mycorrhiza 22, 203-217. doi: 10.1007/s00572-011-0392-0

Ferreira, A., and Lima-Costa, M. (2008). Growth and ultrastructural characteristics of Citrus cells grown in medium containing NaCl. Biol. Plant. 52, 129-132. doi: 10.1007/s10535-008-0026-3

Giannopotitis, C. N., and Ries, S. K. (1977). Superoxide dismutase in higher plants. Plant Physiol. 59, 309-314. doi: 10.1104/pp.59.2.309

Greenway, H., and Munns, R. (1980). Mechanisms of Salt Tolerance in Nonhalophytes. Annu. Rev. Plant Physiol. 31, 149-190. doi: 10.1146/annurev.pp. 31.060180.001053

Gupta, B., and Huang, B. (2014). Mechanism of salinity tolerance in plants: physiological, biochemical, and molecular characterization. Int. J. Genom. 2014:701596. doi: 10.1155/2014/701596

Han, Q. Q., Lü, X.P., Bai, J. P., Qiao, Y., Paré, P. W., Wang, S. M., et al. (2014) Beneficial soil bacterium Bacillus subtilis (GB03) augments salt tolerance of white clover. Front. Plant Sci. 5:525. doi: 10.3389/fpls.2014.00525

Hasegawa, P. M., Bressan, R. A., Zhu, J. K., and Bohnert, H. J. (2000). Plant cellular and molecular responses to high salinity. Annu. Rev. Plant Biol. 51, 463-499. doi: 10.1146/annurev.arplant.51.1.463

Hernández, J. A., Corpas, F. J., Gómez, M., Del-Río, L. A., and Sevilla, F (1993). Salt-induced oxidative stress mediated by activated oxygen species in pea leaf mitochondria. Physiol. Plant. 89, 103-110. doi: 10.1111/j.13993054.1993.tb01792.x

Hmida-Sayari, A., Gargouri-Bouzid, R., Bidani, A., Jaoua, L., Savouré, A., and Jaoua, S. (2005). Overexpression of ${ }^{\Delta} 1$-pyrroline-5-carboxylate synthetase increases proline production and confers salt tolerance in transgenic potato plants. Plant Sci. 169, 746-752. doi: 10.1016/j.plantsci.2005.05.025

Hodges, D. M., John, M. D., Charles, F. F., and Robert, K. P. (2014). Improving the thiobarbituric acid-reactive-substances assay for estimating lipid peroxidation in plant tissues containing anthocyanin and other interfering compounds. Planta 207, 604-611. doi: 10.1007/s004250050524

Hossain, Z., Mandal, A. K. A., Shukla, R., and Datta, S. K. (2004). NaCl stressits chromotoxic effects and antioxidant behavior in roots of Chrysanthemum morifolium Ramat. Plant Sci. 166, 215-220. doi: 10.1016/j.plantsci.2003.09.009

Hou, X., Liang, Y., He, X., Shen, Y., and Huang, Z. (2013). A novel ABA-responsive TaSRHP gene from wheat contributes to enhanced resistance to salt stress in Arabidopsis thaliana. Plant Mol. Biol. Rep. 31, 791-801. doi: 10.1007/s11105012-0549-9

Huang, Z., Zhao, L., Chen, D., Liang, M., Liu, Z., Shao, H., et al. (2013). Salt stress encourages proline accumulation by regulating proline biosynthesis and degradation in Jerusalem artichoke plantlets. PloS ONE 8:e62085. doi: 10.1371/journal.pone.0062085

Jing, X., Hou, P., Lu, Y., Deng, S., Li, N., Zhao, R., et al. (2014). Overexpression of copper/zinc superoxide dismutase from mangrove Kandelia candel in tobacco enhances salinity tolerance by the reduction of reactive oxygen species in chloroplast. Front. Physiol. 5:515. doi: 10.3389/fphys.2014.00515

Kader, M. A., and Lindberg, S. (2005). Uptake of sodium in protoplasts of saltsensitive and salt-tolerant cultivars of rice, Oryza sativa L. determined by the fluorescent dye SBFI. J. Exp. Bot. 56, 3149-3158. doi: 10.1093/jxb/eri312

Katerji, N., Van-Hoorn, J., Hamdy, A., and Mastrorilli, M. (2000). Salt tolerance classification of crops according to soil salinity and to water stress day index. Agric. Water Manage. 43, 99-109. doi: 10.1016/S0378-3774citation(99)00048-7

Khayyat, M., Tehranifar, A., Davarynejad, G. H., and Sayyari-Zahan, M. H. (2014). Vegetative growth, compatible solute accumulation, ion partitioning and chlorophyll fluorescence of 'Malas-e-Saveh' and 'Shishe-Kab' pomegranates in response to salinity stress. Photosynthetica 52, 301-312. doi: 10.1007/s11099014-0034-9

Khelil, A., Menu, T., and Ricard, B. (2007). Adaptive response to salt involving carbohydrate metabolism in leaves of a salt-sensitive tomato cultivar. Plant Physiol. Biochem. 45, 551-559. doi: 10.1016/j.plaphy.2007.05.003

Kim, I., and Park, S. (2010). Ultrastructural characteristics of three chenopod halophytes lacking salt excretion structures. J. Plant Biol. 53, 314-320. doi: 10.1007/s12374-010-9119-6

Koca, H., Ozdemir, F., and Turkan, I. (2006). Effect of salt stress on lipid peroxidation and superoxide dismutase and peroxidase activities of Lycopersicon esculentum and L. pennellii. Biol. Plant. 50, 745-748. doi: 10.1007/s10535-0060121-2
Krantev, A., Yordanova, R., Janda, T., Szalai, G., and Popova, L. (2008). Treatment with salicylic acid decreases the effect of cadmium on photosynthesis in maize plants. J. Plant Physiol. 165, 920-931. doi: 10.1016/j.jplph.2006.11.014

Kronzucker, H. J., Szczerba, M. W., Moazami-Goudarzi, M., and Britto, D. T. (2006). The cytosolic $\mathrm{Na}^{+}: \mathrm{K}^{+}$ratio does not explain salinity-induced growth impairment in barley: a dual-tracer study using $42 \mathrm{~K}^{+}$and $24 \mathrm{Na}^{+}$. Plant Cell Environ. 29, 2228-2237. doi: 10.1111/j.1365-3040.2006.01597.x

Krzesłowska, M. (2010). The cell wall in plant cell response to trace metals: polysaccharide remodeling and its role in defense strategy. Acta Physiol. Plant. 33, 35-51. doi: 10.1007/s11738-010-0581-Z

Lai, D., Mao, Y., Zhou, H., Li, F., Wu, M., and Zhang, J., et al. (2014). Endogenous hydrogen sulfide enhances salt tolerance by coupling the reestablishment of redox homeostasis and preventing salt-induced $\mathrm{K}^{+}$loss in seedlings of Medicago sativa. Plant Sci. 225, 117-129. doi: 10.1016/j.plantsci.2014.06.006

Liu, W., Yuan, X., Zhang, Y., Xuan, Y., and Yan, Y. (2014a). Effects of salt stress and exogenous $\mathrm{Ca}^{2+}$ on $\mathrm{Na}^{+}$compartmentalization, ion pump activities of tonoplast and plasma membrane in Nitraria tangutorum Bobr. leaves. Acta Physiol. Plant. 36, 2183-2193. doi: 10.1007/s11738-014-1595-8

Liu, X., Mak, M., Babla, M., Wang, F., Chen, G., Veljanoski, F., et al. (2014b) Linking stomatal traits and expression of slow anion channel genes HvSLAH1 and $H v S L A C 1$ with grain yield for increasing salinity tolerance in barley. Front. Plant Sci. 5:634. doi: 10.3389/fpls.2014.00634

Lu, Y., Li, N., Sun, J., Hou, P., Jing, X., and Zhu, H., et al. (2013). Exogenous hydrogen peroxide, nitric oxide and calcium mediate root ion fluxes in two nonsecretor mangrove species subjected to $\mathrm{NaCl}$ stress. Tree Physiol. 33, 81-95. doi: 10.1093/treephys/tps119

Luna, C., Seffino, L. G., Arias, C., and Taleisnik, E. (2000). Oxidative stress indicators as selection tools for salt tolerance in Chloris gayana. Plant Breed. 119, 341-345. doi: 10.1046/j.1439-0523.2000.00504.x

Lv, S., Nie, L., Fan, P., Wang, X., Jiang, D., Chen, X., et al. (2011). Sodium plays a more important role than potassium and chloride in growth of Salicornia europaea. Acta Physiol. Plant. 34, 503-513. doi: 10.1007/s11738-011-0847-0

Ma, Q., Yue, L. J., Zhang, J. L., Wu, G. Q., Bao, A. K., and Wang, S. M. (2012). Sodium chloride improves photosynthesis and water status in the succulent xerophyte Zygophyllum xanthoxylum. Tree Physiol. 32, 4-13. doi: 10.1093/treephys/tpr098

Maathuis, F. J. M. (2014). Sodium in plants: perception, signalling, and regulation of sodium fluxes. J. Exp. Bot. 65, 849-858. doi: 10.1093/jxb/ert326

Maathuis, F. J. M., Ahmad, I., and Patishtan, J. (2014). Regulation of $\mathrm{Na}^{+}$fluxes in plants. Front. Plant Sci. 5:467. doi: 10.3389/fpls.2014.00467

Maathuis, F. J. M., and Amtmann, A. (1999). $\mathrm{K}^{+}$nutrition and $\mathrm{Na}^{+}$toxicity: the basis of cellular $\mathrm{K}^{+} / \mathrm{Na}^{+}$ratios. Ann. Bot. 84, 123-133. doi: 10.1006/anbo.1999.0912

Miao, B. H., Han, X. G., and Zhang, W. H. (2010). The ameliorative effect of silicon on soybean seedlings grown in potassium-deficient medium. Ann. Bot. 105, 967-973. doi: 10.1093/aob/mcq063

Mishra, P., Bhoomika, K., and Dubey, R. (2011). Differential responses of antioxidative defense system to prolonged salinity stress in salt-tolerant and saltsensitive Indica rice (Oryza sativa L.) seedlings. Protoplasma 250, 3-19. doi: 10.1007/s00709-011-0365-3

Mitsuya, S., Takeoka, Y., and Miyake, H. (2000). Effects of sodium chloride on foliar ultrastructure of sweet potato (Ipomoea batatas Lam.) plantlets grown under light and dark conditions in vitro. J. Plant Physiol. 157, 661-667. doi: 10.1016/S0176-1617 citation(00)80009-7

Mittova, V., Guy, M., Tal, M., and Volokita, M. (2004). Salinity up-regulates the antioxidative system in root mitochondria and peroxisomes of the wild salttolerant tomato species Lycopersicon pennellii. J. Exp. Bot. 55, 1105-1113. doi: $10.1093 /$ jxb/erh113

Miyake, H., Mitsuya, S., and Rahman, M. S. (2006). "Ultrastructural effects of salinity stress in higher plants," in Abiotic Stress Tolerance in Plants, eds R. Ashwanik and T. Teruhiro (Dordrecht: Springer), 215-226.

Munns, R., and Tester, M. (2008). Mechanisms of salinity tolerance. Annu. Rev. Plant Biol. 59, 651-681. doi: 10.1146/annurev.arplant.59.032607.092911

Naeini, M. R., Khoshgoftarmanesh, A. H., and Fallahi, E. (2006). Partitioning of chlorine, sodium, and potassium and shoot growth of three pomegranate cultivars under different levels of salinity. J. Plant Nutr. 29, 1835-1843. doi: $10.1080 / 01904160600899352$

Navarro, A., Bañon, S., Olmos, E., and Sánchez-Blanco, M. D. J. (2007). Effects of sodium chloride on water potential components, hydraulic conductivity, 
gas exchange and leaf ultrastructure of Arbutus unedo plants. Plant Sci. 172, 473-480. doi: 10.1016/j.plantsci.2006.10.006

Neocleous, D., and Vasilakakis, M. (2007). Effects of $\mathrm{NaCl}$ stress on red raspberry (Rubus idaeus L. 'Autumn Bliss'). Sci. Horticult. 112, 282-289. doi: 10.1016/j.scienta.2006.12.025

Nounjan, N., Nghia, P. T., and Theerakulpisut, P. (2012). Exogenous proline and trehalose promote recovery of rice seedlings from salt-stress and differentially modulate antioxidant enzymes and expression of related genes. J. Plant Physiol. 169, 596-604. doi: 10.1016/j.jplph.2012.01.004

Peng, Y. H., Zhu, Y. F., Mao, Y. Q., Wang, S. M., Su, W. A., and Tang, Z. C. (2004). Alkali grass resists salt stress through high $\left[\mathrm{K}^{+}\right]$and an endodermis barrier to $\mathrm{Na}^{+}$. J. Exp. Bot. 55, 939-949. doi: 10.1093/jxb/erh071

Plett, D. C., and Moller, I. S. (2010). $\mathrm{Na}^{+}$transport in glycophytic plants: what we know and would like to know. Plant Cell Environ. 33, 612-626. doi: 10.1111/j.1365-3040.2009.02086.x

Queirós, F., Fontes, N., Silva, P., Almeida, D., Maeshima, M., Gerós, H., et al. (2009). Activity of tonoplast proton pumps and $\mathrm{Na}^{+} / \mathrm{H}^{+}$exchange in potato cell cultures is modulated by salt. J. Exp. Bot. 60, 1363-1374. doi: 10.1093/jxb/erp011

Queirós, F., Rodrigues, J. A., Almeida, J. M., Almeida, D. P., and Fidalgo, F. (2011). Differential responses of the antioxidant defence system and ultrastructure in a salt-adapted potato cell line. Plant Physiol. Biochem. 49, 1410-1419. doi: 10.1016/j.plaphy.2011.09.020

Rivero, R. M., Mestre, T. C., Mittler, R., Rubio, F., Garcia-Sanchez, F., and Martinez, V. (2014). The combined effect of salinity and heat reveals a specific physiological, biochemical and molecular response in tomato plants. Plant Cell Environ. 37, 1059-1073. doi: 10.1111/pce.12199

Roy, S. J., Negrão, S., and Tester, M. (2014). Salt resistant crop plants. Curr. Opin. Biotechnol. 26, 115-124. doi: 10.1016/j.copbio.2013.12.004

Ruan, C. J., Qin, P., He, Z. X., and Xie, M. (2005). Concentrations of major and minor mineral elements in different organs of Kosteletzkya virginica and saline soils. J. Plant Nutr. 28, 1191-1200. doi: 10.1081/PLN-200063228

Ruffino, A., Rosa, M., Hilal, M., González, J., and Prado, F. (2010). The role of cotyledon metabolism in the establishment of quinoa (Chenopodium quinoa) seedlings growing under salinity. Plant Soil 326, 213-224. doi: 10.1081/pln200063228

Sabatini, D. D., Bensch, K., and Barrnett, R. J. (1963). Cytochemistry and electron microscopy. The preservation of cellular ultrastructure and enzymatic activity by aldehyde fixation. J. Cell Biol. 17, 19-58. doi: 10.1083/jcb.17.1.19

Sabra, A., Daayf, F., and Renault, S. (2012). Differential physiological and biochemical responses of three Echinacea species to salinity stress. Sci. Horticult. 135 23-31. doi: 10.1016/j.scienta.2011.11.024

Sekmen, A. H., Turkan, I., and Takio, S. (2007). Differential responses of antioxidative enzymes and lipid peroxidation to salt stress in salt-tolerant Plantago maritima and salt-sensitive Plantago media. Physiol. Plant. 131, 399-411. doi: 10.1111/j.1399-3054.2007.00970.x

Serraj, R., and Sinclair, T. (2002). Osmolyte accumulation: can it really help increase crop yield under drought conditions? Plant Cell Environ. 25, 333-341. doi: 10.1046/j.1365-3040.2002.00754.x

Shabala, S., and Cuin, T. A. (2008). Potassium transport and plant salt tolerance. Physiol. Plant. 133, 651-669. doi: 10.1111/j.1399-3054.2007.01008.x

Shabala, S., and Pottosin, I. (2014). Regulation of potassium transport in plants under hostile conditions: implications for abiotic and biotic stress tolerance. Physiol. Plant. 151, 257-279. doi: 10.1111/ppl.12165

Shabala, S., Bose, J., and Hedrich, R. (2014). Salt bladders: do they matter? Trends Plant Sci. 19, 687-691. doi: 10.1016/j.tplants.2014.09.001

Shu, S., Yuan, L. Y., Guo, S. R., Sun, J., and Yuan, Y. H. (2013). Effects of exogenous spermine on chlorophyll fluorescence, antioxidant system and ultrastructure of chloroplasts in Cucumis sativus L. under salt stress. Plant Physiol. Biochem. 63, 209-216. doi: 10.1016/j.plaphy.2012.11.028

Silva-Ortega, C. O., Ochoa-Alfaro, A. E., Reyes-Agüero, J. A., Aguado-Santacruz, G. A., and Jiménez-Bremont, J. F. (2008). Salt stress increases the expression of p $5 \mathrm{cs}$ gene and induces proline accumulation in cactus pear. Plant Physiol. Biochem. 46, 82-92. doi: 10.1016/j.plaphy.2007.10.011

Spurr, A. R. (1969). A low-viscosity epoxy resin embedding medium for electron microscopy. J. Ultrastruct. Res. 26, 31-43. doi: 10.1016/s00225320citation(69)90033-1

Stewart, R. R., and Bewley, J. D. (1980). Lipid peroxidation associated with accelerated aging of soybean axes. Plant Physiol. 65, 245-248. doi: 10.1104/pp.65.2.245
Su, X., Chu, Y., Li, H., Hou, Y., Zhang, B., Huang, Q., et al. (2011). Expression of multiple resistance genes enhances tolerance to environmental stressors in transgenic poplar (Populus $\times$ euramericana 'Guariento'). PLoS ONE 6:e24614. doi: 10.1371/journal.pone.0024614

Sun, J., Dai, S., Wang, R., Chen, S., Li, N., and Zhou, X., et al. (2009). Calcium mediates root $\mathrm{K}^{+} / \mathrm{Na}^{+}$homeostasis in poplar species differing in salt tolerance. Tree Physiol. 29, 1175-1186. doi: 10.1093/treephys/tpp048

Takahashi, R., Nishio, T., Ichizen, N., and Takano, T. (2007). Salt-tolerant reed plants contain lower $\mathrm{Na}^{+}$and higher $\mathrm{K}^{+}$than salt-sensitive reed plants. Acta Physiol. Plant. 29, 431-438. doi: 10.1007/s11738-007-0052-3

Tattini, M., and Traversi, M. L. (2009). On the mechanism of salt tolerance in olive (Olea europaea L.) under low or high $\mathrm{Ca}^{2+}$ supply. Environ. Exp. Bot. 65, 72-81. doi: 10.1016/j.envexpbot.2008.01.005

Tester, M., and Davenport, R. (2003). $\mathrm{Na}^{+}$tolerance and $\mathrm{Na}^{+}$transport in higher plants. Ann. Bot. 91, 503-527. doi: 10.1093/aob/mcg058

Vij, S., and Tyagi, A. K. (2007). Emerging trends in the functional genomics of the abiotic stress response in crop plants. Plant Biotechnol. J. 5, 361-380. doi: 10.1111/j.1467-7652.2007.00239.x

Waditee, R., Bhuiyan, N. H., Hirata, E., Hibino, T., Tanaka, Y., Shikata, M., et al. (2007). Metabolic engineering for betaine accumulation in microbes and plants. J. Biol. Chem. 282, 34185-34193. doi: 10.1074/jbc.M704939200

Wang, Y. C., Qu, G. Z., Li, H. Y., Wu, Y. J., Wang, C., Liu, G. F., et al. (2010). Enhanced salt tolerance of transgenic poplar plants expressing a manganese superoxide dismutase from Tamarix androssowii. Mol. Biol. Rep. 37, 1119-1124. doi: 10.1007/s11033-009-9884-9

Wang, Y., and Wu, W. H. (2010). Plant sensing and signaling in response to $\mathrm{K}^{+}$ deficiency. Mol. Plant 3, 280-287. doi: 10.1093/mp/ssq006

Wang, Z. Q., Yuan, Y. Z., Ou, J. Q., Lin, Q. H., and Zhang, C. F. (2007). Glutamine synthetase and glutamate dehydrogenase contribute differentially to proline accumulation in leaves of wheat (Triticum aestivum) seedlings exposed to different salinity. J. Plant Physiol. 164, 695-701. doi: 10.1016/j.jplph.2006.05.001

Wilkinson, S., and Davies, W. J. (2002). ABA-based chemical signalling: the coordination of responses to stress in plants. Plant Cell Environ. 25, 195-210. doi: 10.1046/j.0016-8025.2001.00824.x

Xue, Z., Zhao, S., Gao, H., and Sun, S. (2013). The salt resistance of wild soybean (Glycine soja Sieb. et Zucc. ZYD 03262) under $\mathrm{NaCl}$ stress is mainly determined by $\mathrm{Na}^{+}$distribution in the plant. Acta Physiol. Plant. 36, 61-70. doi: 10.1007/s11738-013-1386-7

Yamane, K., Rahman, M. S., Kawasaki, M., Taniguchi, M., and Miyake, H. (2004). Pretreatment with antioxidants decreases the effects of salt stress on chloroplast ultrastructure in rice leaf segments (Oryza sativa L.). Plant Prod. Sci. 7, 292-300. doi: 10.1626/pps.7.292

Yamori, W., Suzuki, K., Noguchi, K., Nakai, M., and Terashima, I. (2006). Effects of Rubisco kinetics and Rubisco activation state on the temperature dependence of the photosynthetic rate in spinach leaves from contrasting growth temperatures. Plant Cell Environ. 29, 1659-1670. doi: 10.1111/j.1365-3040.2006.01550.x

Yao, R., and Fang, S. (2008). Effect of $\mathrm{NaCl}$ stress on ion distribution in roots and growth of Cyclocarya paliurus seedlings. Front. Forest. China 4, 208-215. doi: 10.1007/s11461-009-0007-5

Yazici, I., Tuerkan, I., Sekmen, A. H., and Demiral, T. (2007). Salinity tolerance of purslane (Portulaca oleracea L.) is achieved by enhanced antioxidative system, lower level of lipid peroxidation and proline accumulation. Environ. Exp. Bot. 61, 49-57. doi: 10.1016/j.envexpbot.2007.02.010

Yousfi, S., Rabhi, M., Hessini, K., Abdelly, C., and Gharsalli, M. (2010). Differences in efficient metabolite management and nutrient metabolic regulation between wild and cultivated barley grown at high salinity. Plant Biol. 12, 650-658. doi: 10.1111/j.1438-8677.2009.00265.x

Zhang, J. L., and Shi, H. (2013). Physiological and molecular mechanisms of plant salt tolerance. Photosynth. Res. 115, 1-22. doi: 10.1007/s11120-013-9813-6

Zhang, J. L., Flowers, T. J., and Wang, S. M. (2010). Mechanisms of sodium uptake by roots of higher plants. Plant Soil 326, 45-60. doi: 10.1007/s11104-0090076-0

Zhang, X., Lu, G., Long, W., Zou, X., Li, F., and Nishio, T. (2014). Recent progress in drought and salt tolerance studies in Brassica crops. Breed. Sci. 64, 60-73. doi: $10.1270 /$ jsbbs. 64.60

Zhao, F. Y., and Zhang, H. (2006). Salt and paraquat stress tolerance results from co-expression of the Suaeda salsa glutathione S-transferase and catalase in transgenic rice. Plant Cell Tiss. Org. 86, 349-358. doi: 10.1007/s11240-006-9133-z 
Zhou, J., Wang, J. J., and Bi, Y. F. (2014). Overexpression of PtSOS2 enhances salt tolerance in transgenic poplars. Plant Mol. Biol. Rep. 32, 185-197. doi: 10.1007/s11105-013-0640-x

Zhu, J. K. (2002). Salt and drought stress signal transduction in plants. Annu. Rev. Plant Biol. 53, 247-273. doi: 10.1146/annurev.arplant.53.091401.143329

Conflict of Interest Statement: The authors declare that the research was conducted in the absence of any commercial or financial relationships that could be construed as a potential conflict of interest.

Received: 21 August 2014; accepted: 18 December 2014; published online: 13 January 2015.
Citation: Gao H-J, Yang H-Y, Bai J-P, Liang X-Y, Lou Y, Zhang J-L, Wang D, Zhang JL, Niu S-Q and Chen Y-L (2015) Ultrastructural and physiological responses of potato (Solanum tuberosum L.) plantlets to gradient saline stress. Front. Plant Sci. 5:787. doi: $10.3389 /$ fpls.2014.00787

This article was submitted to Plant Physiology, a section of the journal Frontiers in Plant Science.

Copyright (c) 2015 Gao, Yang, Bai, Liang, Lou, Zhang, Wang, Zhang, Niu and Chen. This is an open-access article distributed under the terms of the Creative Commons Attribution License (CC BY). The use, distribution or reproduction in other forums is permitted, provided the original author(s) or licensor are credited and that the original publication in this journal is cited, in accordance with accepted academic practice. No use, distribution or reproduction is permitted which does not comply with these terms. 